UNIVERSIDADE DE SÃO PAULO

INSTITUTO DE QUÍMICA

ATIVIDADE DE ENZIMAS DO METABOLISMO DE COMPOSTOS SECUNDÁRIOS COMPROMETIDOS COM O ENRAIZAMENTO "IN VITRO" DE Eucalyptus grandis HILL ex MAIDEN

AUTOR: Isaac Stringueta Machado

ORIENTADOR: Prof. Dr. Otto Jesu Crocomo

SÃO PAULO

1993 
ATIVIDADE DE ENZIMAS DO METABOLISMO DE COMPOSTOS SECUNDÁRIOS COMPROMETIDOS COM O ENRAIZAMENTO "IN VITRO" DE Eucalyptus grandis HILL ex MAIDEN

\section{AUTOR : ISAAC STRINGUETA MACHADO}

Tese de Doutorado submetida ao Instituto de Química da Universidade de São Paulo como parte dos requisitos necessários à obtenção do grau de Doutor em Ciências - área de concentração Bioquímica.

Aprovada por:

Prof. Dr. Otto Jesu Crocomo, CEBTEC-ESALQ-USP (Orientador e Presidente)

Prof. Dr. José etartos da Costa Maia, IQ-USP

Prof. Dr. Antonio Natal Gonçalves, ESALQ-USP

Prof. Dr. Joâd Domingos Rodrigues, IB-UNESP

Prof. Dr. Celso Rossi, IB-UNESP

SÃO PAULO, S.P.

18 DE NOVEMBRO DE 1993 
Em memória de minha mãe

DORMINA STRINGUETA MACHADO 


\section{AGRADECIMENTOS}

- Prof. Dr. Otto Jesu Crocomo, pela orientação cientifica e cessão de material e equipamento dos laboratórios do Centro de Biotecnologia Agricola (CEBTEC)USP - Piracicaba.

- Antonio F. de Campos Amaral, Egidio Miguel Campagnol, Maria Solizete Granziol Silva e José Luiz Couto; técnicos, secretária e estagiário do CEBTEC.

- Ana Cristina Pardini de Melo, Adalberto Francisco dos Santos e José Luis Barbosa de Souza, secretária e técnicos da FCA e FMVZЛNESP - Botucatu.

- Dr. Roberto Boneti, pela elaboração do material fotográfico.

- Funcionários da Seção de Pós Graduação do IQUSP - São Paulo.

- Departamento de Ciências Ambientais - FCAUNESP - Botucalu, na pessoa do Prof. Dr. Antenor Pasqual, pela oportunidade de realização do programa de Doutorado no IQUSP-São Paulo.

- Coordenadoria de Apoio a Pessoal de Nivel Superior (CAPES).

- À todos que direta ou indiretamente contribuiram para a realização deste trabalho. 


\section{ÍNDICE}

Item

Páginas

RESUMO

i

SUMMARY

ii

1 INTRODUÇÃO

2 REVISÃO DE LITERATURA

2.1 O METABOLISMO DE COMPOSTOS SECUNDÁRIOS (FENILPROPANO) E AS ENZIMAS PAL E G-6P-DH, EM PLANTAS SUPERIORES

2.2 A HIDROXILAÇÃO E A FORMAÇÃO DE FLAVONÓIDES E DIHIRO FLAVONOIS

2.3 A FUNÇ̃̃O DOS COMPOSTOS FLAVONÓDES NA RESPOSTA AO "STRESS" FISIOLÓGICO, FTTOPATOLÓGICO E COMPROMETTMENTO COM O ENRAIZAMENTO.

2.4 A MICROPROPAGACÃO DO EUCALIPTO E OS PROBLEMAS DO ENRAIZAMENTO DIRETO "IN VITRO"

3 MATERIAL E MÉTODOS

3.1 PLANTAS MATREES

3.2 OBTENÇÃO E DESINFECC̊̃̃O DOS EXPLANTES

3.3 INOCULAÇÃO E MICROPROPAGAÇÃO DAS GEMAS EPICÓRMICAS: MEIOS DE CULTURA, CONDIÇÕES AMBIENTAIS, PROCEDIMENTOS E AVALIAC,ÃO

3.4 ALONGAMENTO DAS GEMAS MICROPROPAGADAS: MEIO DE CULTURA, CONDIÇÕES AMBIENTAIS, PROCEDIMENTOS E AVALIAÇÕES 
3.5 INFLUÊNCIA DO SUPRIMENTO DE AUXINA EXÓGENA (AIB) NO ENRAIZAMENTO "IN VTTRO" DAS GEMAS ALONGADAS

3.5.1 Avaliação da frequência do enraizamento "in vitro"

3.5.2 Obtenção dos Extratos de Plantas e Preparo das Amostras

3.5.3 Determinação do teor de proteina

3.5.4 Análise da atrvidade enzimática da Fenilalanina Amônia-tiase (PAL)

3.5.5 Análise da atividade enzinática da Glucose-6-Fosfato Desidrogenase (G6P-DH)

4 RESULTADOS E DISCUSSÃO

4.1 TAXA DE MULTIPLICAÇÃO DAS BROTAÇÕES EPICÓRMICAS

4.2 FREQUENCLA DE ALONGAMENTO DAS GEMAS MICROPROPAGADAS

4.3 FREQÜENCLIA DE ENRAIZAMENTO "IN VTTRO"

4.4 COMPORTAMENTO DOS CLONES EM PRODUÇ̃̃O DE MASSAS DE MATÉRLAS FRESCA E SECA. "IN VITRO"

4.5 COMPORTAMENTO DOS CLONES EM RELAÇ̃̃O AO TEOR PROTÉICO

4.6 ATTVIDADE ENZIMÁTICA DE FENILALANINA AMÔNIA-LIASE

4.7 ATTVIDADE ENZIMÁTTCA DE GLUCOSE-6-FOSFATO-DESIDROGENASE (G-6P-DH)

6 REFERÊNCIAS BIBLIOGRÁFICAS 


\section{ÍNDICE DE FIGURAS}

Figuras

Páginas

1 Metabolismo parcial do Fenilpropano e a biossíntese de compostos flavonóides, depois de FRTCH \& GRISEBACH, 1975; SEYFERT, 1982; SCHUTTE, 1985: HENKEL-RIEGER, 1989: STICH ef alii, 1992.

2 Esquema geral do Metabolismo do Fenilpropano (JONES, 1984; TANAKA et alii. 1992).

3 As principais classes dos compostos flavonóides (HINDERER \& SETT, 1988)

4 Evolução das brotações epicómicas prochuzidas, petos explantes iniciais (tufo de 5 brotações) dos clones GO 669; GO 682 e GO 250, durante 4 subcultivos sucessivos, em meio básico suplementado com $0,2 \mathrm{mg} / \mathrm{l}$ de BAP

5 Multiplicação "in vitro" de gemas do clone $G O 250$, de Eucalyptus grandis Hill ex Maiden

6 e 7 Multiplicação "in vitso" de gemas dos clones GO 669 e GO 682, de Eucalyptus grandis Hill ex Maiden.

8 e 9 Alongamento de gemas dos clones GO 250 (superior) e GO 669 (inferior) de Eucalyptus grandis Hill ex Maiden, "in vitro"

10 Alongamento de gemas do clone GO 682 de Eucalyptus grandis Hill ex Maiden, "in vitro"

11 Freqüência de culturas dos clones GO 250; GO 669 e GO 682 que desenvolveram raiz. em meio de cultura básico de GONÇALVES (1980), suplementado com 0,$0 ; 0,1 ; 0,5 ; 1,0$ e $1,5 \mathrm{mg} / \mathrm{l}$ de $\mathrm{AIB}$

12 e 13 Enraizamento de gemas dos clones GO 682 (esquerda) e GO 669 (direita) de Eucalyptus granais Hill ex Maiden. "in vitro" 
14 Enraizamento de gemas do clone GO 250, de Eucalyptus grandis Hill ex Maiden "in vitro"

15 Comportamento dos clones GO 250; GO 669 e GO 682, em relação à produção de massa de matéria fresca (g/planta) das brotações que enraizaram, ou não. OS números representam valores médios de 15 repetições. () Tl-gnupo com raiz, não apresentou material suficiente para a determinação.

16 Comportamento dos clones GO 250; GO 669 e GO 682, em relação à produção de massa de matéria seca ( $g$ /planta) das brotações que enraizaram, ou não. Os números representam valores médios de 15 repetições. O T1-gnupo com raiz, não apresentou material suficiente para a determiną̧ão.

17 Comportamento dos clones GO 250; GO 669 e GO 682 em relação ao teor protéico $(\mathrm{mg} / \mathrm{ml})$ das brotações que enraizaram, ou não. Os números representam valores médios de 5 repetições, analisadas com 3 duplicatas cada.

18 Efeito do suprimento de auxina (AIB) exógena sobre a atividade da enzima fenilalanina amônia-liase (PAL), no emraizamento direto de brotações de Eucalyptus grandis Hill ex Maiden (clones GO 250, GO 669 e GO 682), cultivadas "in vitro"

19 Efeito do suprimento crescente de auxina exógena (AIB) sobre a atividade da enzima glicose-6-fosfato-desidrogenase (G-6P-DH), no enraizamento direto de brotações de Eucalyptus grandis Hill ex Maiden (clones GO 250, GO 669 e GO 682), cultivadas "in vitro" 


\section{ÍNDICE DE QUADROS E TABELAS}

1 Sais de GONÇALVES (1980) inodificados (SGM)- Meio de Cultura Básico

2 Componentes Orgânicos-Meio de Cultura Básico, segundo GONÇALVES (1980)

3 Freqüência de culturas com brotações alongadas $(1)$ dos clones GO 250; GO 669 e GO 682, em meio de cultura básico de GONÇALVES (1980), suplementado com $0,05 \mathrm{mg} / \mathrm{de}$ BAP e $0.05 \mathrm{mg} /$ de AIB

Tabelas

Páginas

1 Produção de matéria fresca (grama/planta) dos clones GO 250; GO 682 e GO 669, que enraizaram, e os que não apresentaram diferenciação em raiz, nos 5 tratamentos testados. Valores médios de 15 repetições

2 Produção de matéria seca (grama/planta) dos clones GO 250; GO 682 e GO 669, que enraizaram, e os que não apresentaram diferenciação em raiz, nos 5 tratamentos testados. Valores médios de 15 repetições

2 Teor protéco (mg prot./ml) dos clones GO 250; GO 682 e GO 669, que enraizaram, e os que não apresentaram diferenciação em raiz, nos 5 tratamentos testados. Valores médios de 15 repetições/grupo, com 3 duplicata cada 


\section{ABREVIATURAS}

PAL - fenilalanina amônia-liase

G-6P-DH - glucose 6-fosiato-desidrogenase

$\mathrm{CAH}$ - ácido cinâmico 4-hidroxilase

4-CL - ácido 4-hidroxi-cinâmico - CoA-ligase

CHS - chalconasintase

$\mathrm{CHI}$ - chalconajsomerase

E.C. - Enzyme Commission - Comissão Enzimática

CoA $\quad-$ coenzima A

M.S. - espectrometria de massa

EI-MS - espectrometria de massa por impacto eletrônico

BAP - benzilaminopurina

AIB - ácido indolilbutírico

ASB - albumina de sôro bovino

Kat $\quad-$ Katal $=\mathrm{mol} / \mathrm{segundo}$

mRNA - ácido ribonucléico - mensageiro

NAD - nicotinamida adenina dinuclentíden

$\mathrm{NADH} \quad$ - nicotinamida adenina dinucleotideo (reduzido)

NADPH - nicotinamida adenina dinucleotideo fosfato (reduzido)

MF - matéria fresca

MS - matéria seca 


\title{
ATIVIDADE DE ENZIMAS DO METABOLISMO DE COMPOSTOS SECUNDÁRIOS COMPROMETIDOS COM O ENRAIZAMENTO "IN VITRO- DE Eucalyptus grandis HILL ex MAIDEN
}

\author{
AUTOR: ISAAC STRINGUETA MACHADO \\ ORIENTADOR: OTTO JESU CROCOMO
}

\section{RESUMO}

o trabalho realizado constitui uma estratégia em Biotecnologia de Plantas para a investigação dos esquemas bioquímicos controladores da diferenciação celular no processo de en raizamento.

Através da técnica da cultura de tecidos "in vitro" foram micropropagados clones de Eucalyptus grandis HILL ex MAIDEN (GO 250, GO 682 e GO 669) selecionadas no CEBTEC/USP.

Em uma pesquisa preliminar foram estabelecidas e multiplicadas gemas, seguida de testes da composição de meios de cultura para elongação e en raizamento. Foram estudadas diversas possibilidades de balanceamento das substâncias reguladoras de crescimento - ácido indolilbutírico (A|B)/ 
benzilaminopurina (BAP). Os clones apresentaram comportamentos anatómico-fisiológicos (massa fresca e seca; teor protéico; taxas de multiplicação das brotações epicórmicas, elongação e en raizamento) diferenciados entre si. As frequências de en raizamento mostraram-se superiores às já observadas por outros autores. Foram estabelecidas, ainda, algumas alterações na composição dos meios de cultura empregados.

Através de experimentos cinéticos foram determinados os padrões de indução e/ou inibição das enzimas fenilalanina amônia-liase (PAL) e glucose 6-fosfato-desidrogenase (G-6P-DH) importantes para a biossíntese de compostos flavonóides, considerados como os principais cofatores das auxinas endógenas no complexo iniciador do en raizamento. Verificou-se que embora o suprimento exógeno crescente de AlB tenha resultado em maiores taxas de enraizamento, as atividades da PAL e G-6P-DH não se mostraram significativamente alteradas. Contudo, foi observado também que as gemas que en raizaram apresentaram atividade da PAL significativamente superior, evidenciando maior fluxo do Metabolismo do Fenilpropano durante o en raizamento. 
ENZYME ACTIVITY OF METABOLISM OF SECONDARY COMPOUNDS RELATED TO "IN VITRO" ROOTING OF Eucalyptus grandis HILL ex MAIDEN

AUTHOR: ISAAC STRINGUETA MACHADO ADVISOR: PrOf. Dr. OTTO JESU CROCOMO

\section{SUMMARY}

This study constitutes a strategy in Plant Biotechnology with the purpose to investigate the regulating biochemical development of the cellular differentiation in the rooting process.

Through plant tissue culture "in vitro" technique, clones of Eucalyptus grandis Hill ex Maiden (GO 250, GO 682 e GO 669) selected at CEBTEC/USP, were microp ropagated.

In a preliminary study shoots were multiplied, followed by tests of media culture composition for shoot elongation and root initiation. Several possibilities and rates of plant growth regulators, indolilbutyric acid (IBA)/benzylaminopurine (BAP) were studied. 
The clones showed different anatomic-physiological behaviours (fresh and oven-dry weight; proteic content; epicormic shoots multiplication rates, elongation and rooting). The frequences of rooting were higher than those described by other authors. Some modifications in the composition of used culture media were also defined.

Through kinetic experiments, induction and inhibition patterns of phenylalanine ammonia-lyase (PAL) and glucose 6phosphate-dehydrogenase $(G-6 P-D H)$ important to the biossyntesis of flavonoid compounds were determined. They were considered as the main cofactors of endogenous auxins in the root stimulating complex. Although, the increasing exogenous supply of AIB resulted in higher rooting rates, the activities of PAL and G-6P-DH enzyme did not present alterations. However, it was also observed that shoots wich rooted, in the treatments, showed higher PAL activity, resulting in higher flux of phenylpropanoid metabolism during the rooting. 


\section{INTRODUÇÃO}

A abordagem biotecnológica através do uso das técnicas de cultivo de tecidos de plantas "in vitro", tem sido cada vez mais empregada na multiplicação e melhoramento de árvores úteis para a melhoria da qualidade da vida, como fruteiras, espécies florestais e nativas ameaçad as de extinção. A maioria dos pesquisadores da área concorda em que a baixa freqũencia de en raizamento, tanto "in vitro" quanto "ex vitro", seja um dos fatores mais limitantes de obtenção e multiplicação de matrizes. A clonagem de matrizes "in vitro" permite, de maneira mais rápida e funcional, a realização das mais diversas investigações científicas. Assim, a elaboração de novos 
meios de cultivo e o aperfeiçoamento daqueles já estabelecidos, vem merecen do maior at en ção.

Estudos fisiológicos conduzidos através da última metade do século estabeleceram o papel dos fitohormónios em praticamente todas as fases do desenvolvimento das plantas. As técnicas clássicas empregadas, por serem imprecisas. levaram a um quadro incopleto da compreensão da ação hormonal. Técnicas da biologia molecular vêm causando maior impacto na investigação da biologia e bioquímica dos fitohormônios.

O desen volvimento das investigações moleculares devem-se muito ao aumento da obtenção de mutantes para estudo do processo hormonal em plantas (King, 1988 e Reid, 1990, citados por KLEE \& ESTELLE, 1991). Os beneficios deste tipo da análise são muitos. Primeiro, a caracterização fenotípica dos mutantes hormonais pode fornecer informações sobre o papel dos hormônios em fisiologia e desenvolvimento da planta. Segundo, mutantes podem ser usados para avaliações bioquimicas da biossintese e ação hormonal. Finalmente, algumas espécies de plantas mutantes podem ser usadas para isolar e caracterizar os genes requeridos para o processo hormonal. A investigação da biologia hormonal em plantas transgênicas tem começado a produzir dados interessantes. Quanto maior o número de genes con hecidos, maior o potencial 
para a compreensão da sintese e ação hormonal, permitindo a manipulação do crescimento e desenvolvimento da planta para propósitos agronômicos e botânicos em geral.

A habilidade dos tecidos de plantas em desenvolver raizes depende das interações entre muitos fatores exógenos e endógenos. O papel das auxinas, naturais ou sintéticas, no en raizamento vem sendo estudado há mais de duas décadas, sendo, o principal fator envolvido no processo. Na complexidade do enraizamento, muitos fatores têm sido considerados, como carboidratos, lipideos, ácido abcísico e outros derivados, mas o que é de consenso de grande parte dos autores é a participação essencial dos cofatores de en raizamento, derivados do Metabolismo de Fenilpropano.

A enzima fenilalanina amónia-liase é extraordinariamente sensível ao estado fisiológico da planta. Mudanças na atividade podem ocorrer durante o crescimento e diferenciação dos tecidos, ou ainda, podem acompanhar eventos traumáticos ou patológicos, e ainda a ação da luz. Muitas combinações de estímulos e sistemas biológicos têm sido investigados. Os estimulos mais estudados são o efeito da luz e aqueles causados por infeç̧ão de microorganismos fitopatogênicos. Ainda, é pequeno o conhecimento dos mecanismos pelos quais os fitorreguladores de crescimento influenciam o nivel de 
atividade da enzima. Sabe-se contudo, que o decréscimo no suprimento de auxina e o aumento de citocinina exógenos, nos meios de cultura, resultam no aumento da atividade da PAL em poucos dias (JONES, 1984).

A glucose-6-f osfato-desidrogenase (G-6P-DH) é a enzima precursora do Metabolismo do Fenilpropano. Pois através dela a glucose-6P é desidrogenada, levando à uma seqüência formadora da fenilalanina, que ao ser desaminada pela ação catalisadora da fenilalanina amônia-liase (PAL) produz ácido t-cinâmico,. A medição da atividade das duas enzimas permite avaliar a intensidade do fluxo para o metabolismo do fenilpropano e, desta maneira, estimar a produção dos compostos flavonóides (KOUKOL \& CONN, 1961; HANSON \& HAVIR, 1981; DOUGLAS et alii, 1992).

Das muitas combinações possíveis na investigação da relação entre a fase precursora, o metabolismo secundário e o en raizamento, uma contribuição interessan te é o estudo das atividades enzimáticas de $G-6 P-D H$ e $P A L$, relacionando diferentes níveis de suprimento de auxina exógena (A|B) e a freqüência e qualidade do en raizamento de plantas "in vitro".

Os objetivos deste estudo consistiram no aperfeiçoamento ou estabelecimento da composição de novos meios de cultura 
para micropropagação de gemas, alongamento e en raizamento direto "in vitro" de clones de Eucalyptus grandis HILL ex MAIDEN (GO 250, GO 682 e GO 669).

Procurou-se, ainda, contribuir para a compreensão do mecanismo bioquímico do en raizamento de plantas, através de ensaios de laboratório, relacionando 0 balanceamento do suprimento de fitorreguladores do crescimento (BAPbenzilaminopurina e AlB-ácido indolilbutírico) e análises da ativação/inibição da cinética das enzimas glucose-6-fosfatodesidrogenase (G-6P-DH) e fenilalanina amónia-liase (PAL), precursora e iniciadora do Metabolismo Secundário das plantas (Fenilp ropano), respectivamente.

Como objetivo final, a discussão da possibilidade de abordagens biotecnológicas visando o incremento efetivo da qualidade e da frequência do en raizamento de plantas, como o controle bioquímico dos fatores investigados através da utilização da técnica da cultura de tecido vegetal "in vitro". 


\section{REVISÃO DE LITERATURA}

2.1 O METABOLISMO DE COMPOSTOS SECUNDÁRIOS (FENILPROPANO) E AS ENZIMAS PAL E G-6P-DH, EM PLANTAS SUPERIORES

A biossintese de certos compostos derivados do benzeno, e encontrados em plantas, tais como ácidos hidroxicinâmicos, lignina, flavonóides, e cumarinas, vem sendo bastante investigada nas últimas décadas (KOUKOL \& CONN, 1961; EDWARDS \& STOKER, 1967; HARBORNE \& WILLIANS, 1972; HARBORNE, 1980; HINDERER \& SEITZ, 1988; SAPKO et alii., 1992; CALIS et alii, 1992; JIA \& LIU, 1992; KOUL et alii, 1993). 
As enzimas que catalisam os diferentes passos da sintese de flavonóides são encontradas em diferentes órgãos e tecidos de plantas (RUSSEL \& GASTON, 1967; BEERHUES et alii, 1989; MO et alii, 1989; TANAKA et alii, 1992; STICH et alii, 1992), como também em cultura de células e organelas isoladas "in vitro" (KREUZALER \& HAHLBROCK, 1975; KREUZALER et alii, 1979; HRAZDINA et alii, 1976, 1986; HRAZDINA, 1982; HAHLBROCK, 1976, 1981; HAHLBROCK \& SCHEEL, 1989; JONES, 1984; HELLER \& FORKMANN, 1988; GLEITZ \& SEITZ, 1989; FUNK \& BRODELIUS, 1990; BROETTO, 1991; HAGENDOORN et alii, 1990; KAKEGAWA et alii, 1991; GUPTA \& CREASY, 1991; NADASKA \& ERDELSKY, 1991; LOAKE et alii, 1991; SAPKO et alii, 1992).

A enzima glucose-6-f osfato-desidrogenase (G-6P-DH, E.C. 1.1.1.49) é reguladora da via das pentose fosfato, geradora de NADPH e ribose 5-fosfato e fornecedora indireta de esqueletos carbônicos para a sintese de aminoácidos aromáticos (fenilalanina e tirosina), substratos para a iniciação do metabolismo do Fenilpropano (Figura 1) (HO et alii, 1988; PARMJIT et alii, 1987; KURLANDSKY et alii, 1988; BOGATEK et alii, 1989; BROET TO, 1991).

A $G-6 P-D H$ cat alisa a reação:

Glucose-6-P $\frac{\text { desidrog enase }}{\mathrm{NAD}_{\mathrm{Mg}} \mathrm{P}^{+}}>$gluconato $6 \mathrm{P}+\mathrm{NAD}(\mathrm{P}) \mathrm{H}^{+} \mathrm{H}^{+}$ 


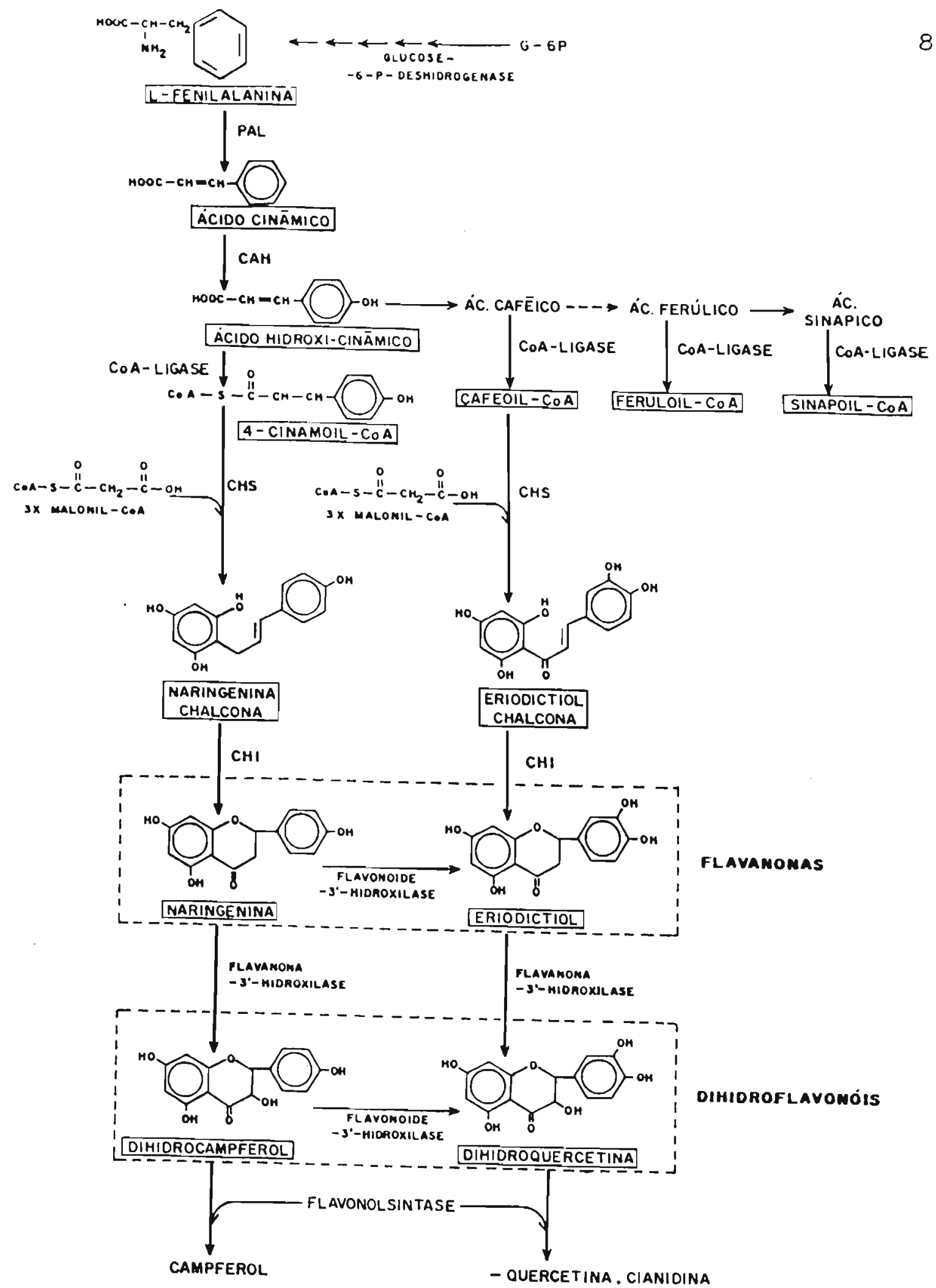

Figura 1. Metabolismo parcial do Fenilpropano, a biossintese de compostos flavonóides, depois de FRITCH \& GRISEBACH, 1975; SEYFERT, 1982; SCHUTTE, 1985; HENKEL-RIEGER, 1989; STICH et alii, 1992. 
A enzima é de particular interesse por aceitar tanto NAD ${ }^{+}$ como NADP' na mesma molécula protéica e, portanto, constituise numa das várias desidrogenases de dupla especificidade de cofator, existentes nos organismos procacarióticos e nos superiores (BRIGHT et alii, 1993).

Os mesmos autores, utilizando técnicas da Biologia Molecular, isolaram e purificaram a $G-6 P-D H$, obtendo valores de PM $39.400( \pm 2000)$ e atividade especifica de $458 \mathrm{U} / \mathrm{mg}$. Quanto à atividade cinética, os valores de $\mathrm{km}$ para a glucose $(9,4 \mathrm{mM})$ e NADP $(0,29 \mathrm{mM})$. Os valores encontrados mostraramse semelhantes aos registrados anteriormente para outros organismos.

Por dosar o fornecimento de substrato para o metabolismo do Fenilpropano, a atividade da G-6P-DH permite avaliar, de maneira indireta, o fluxo e a produção de compostos aromáticos secundários. (BROETTO, 1991).

A fenilalanina amónia-liase (PAL; E.C. 4.3.1.5) é a primeira enzima do metabolismo do Fenilpropano; catalisadora da reação de desaminação da L-fenilalanina, produzindo ácido "trans"cinâmico e amônia (Figuras 1 e 2 ). $O$ ácido cinâmico é o precursor de muitos constituintes secundários em plantas. 


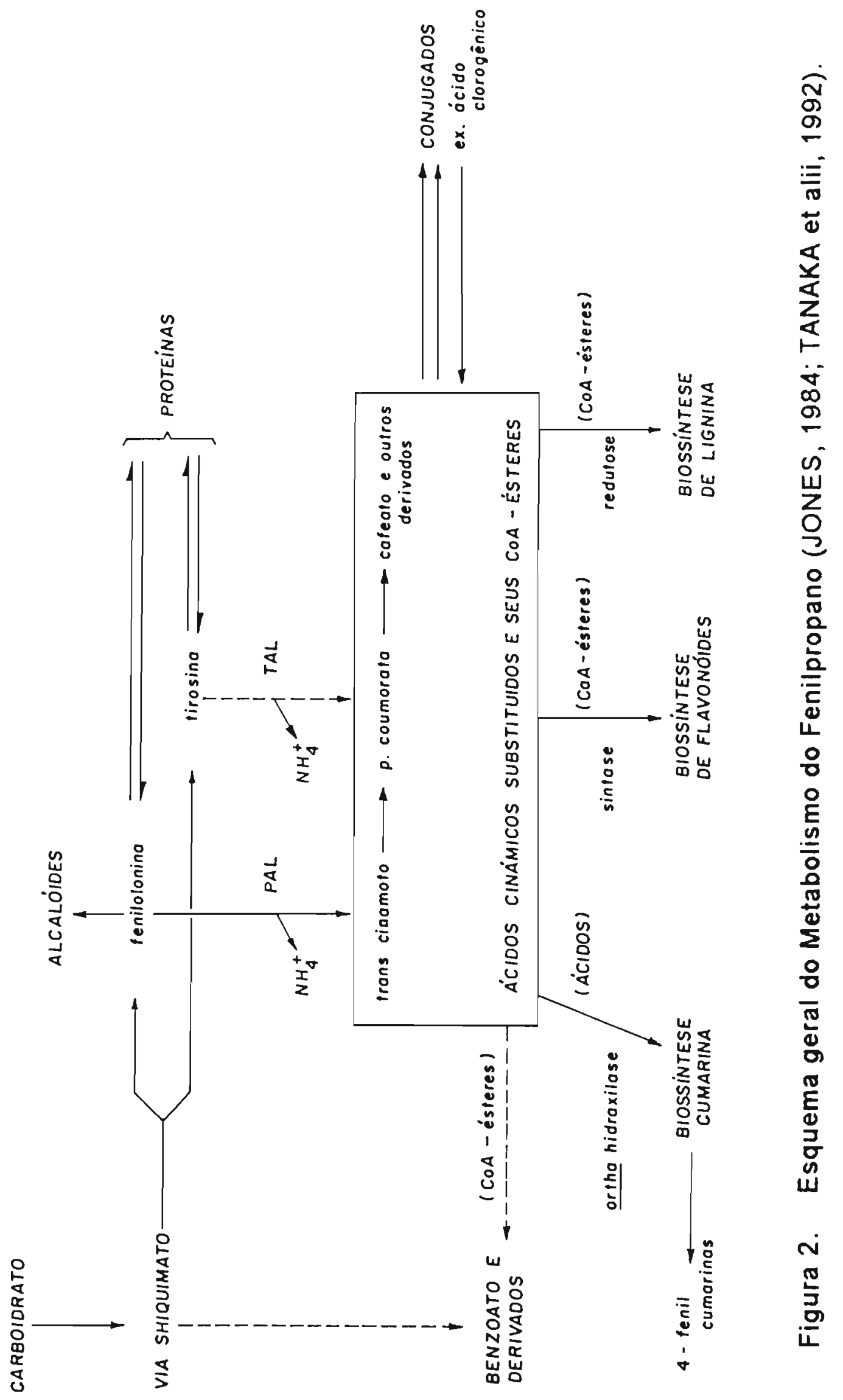


A desaminação ocorre a nivel de citoplasma, e em algumas espécies catalisada através de inúmeras isoenzimas da PAL (BOLWELL et alii, 1985).

Existe um significativo irıteresse pelo estudo da regulação da atividade de PAL, devido ao seu envolvimento na biossintese de compostos fenólicos em plantas. A enzima foi primeiramente descoberta por KOUKOL \& CONN (1961), que a isolaram e caracterizaram em Hordeum vulgare. A partir de então, passou a ser encontrada e descrita em uma grande variedade de plantas (CAMM \& TOWERS, 1974). Alguns anos depois, teve a sua enzimologia, e participação no metabolismo celular, bastante elucidadas pelos estudos de HANSON \& HAVIR, 1981; JONES, 1984; HELLER \& FORKMANN, 1988. Estudos mais recentes confirmam, através da Biologia Molecular, o comportamento $\mathrm{e}$ as características até então descritas (ORNDORFF et alii, 1988; OZEKI, 1990; YOSHIOKA, 1992; YAMADA, 1992) .

Nos estudos pioneiros sobre a PAL, KOUKOL \& CONN (1961) chegaram a algumas conclusões que permitiram identificar e avaliar o comportamento da enzima. A faixa de pH ótimo encontra-se entre os valores de 8,8 a 9,2 , sendo que o sistema é ativado na faixa de $\mathrm{pH} 8,0$ a 10,6 . Quanto à estabilidade térmica, a enzima não apresenta perda de atividade a 
$50^{\circ} \mathrm{C}$ por 10 minutos. A enzima é constituida de 4 subunidades, sen do o P.M. da molécula intacta de aproximadamente 330.000 .

Experimentos preliminares revelaram que a PAL é inibida pelo seu produto final, o ácido t-cinâmico, com uma $\mathrm{km}$ da ordem de $1,7 \times 10^{-3} \mathrm{M}$. Os autores procuraram também determinar a especificidade do sistema, com preparações envolvendo a Dfenilalanina, quando não se observou a produção de ácido cinâmico, o que significa que a enzima tem preferência pela Lfenilalanina como substrato.

O áci do cinâmico-CoA-tioéster não pode ser considerado um produto final da reação de desaminação, mas sim, um "pool" elementar para a sintese de vários produtos secundários, tais como ligninas, flavonóides, taninos, fitoalexinas e alcalóides (GORDON \& KOUKKARI, 1978; HALBROCK, 1981; HALBROCK \& GRISEBACH, 1979; MESSNER et alii, 1991; YOSHIOKA et alii, 1992; YAMADA et alii, 1992).

A PAL já foi purificada e caracterizada em um grande número de plantas e fungos. A divergência de propriedades da enzima entre uma e outra planta, não é maior que aquela observada entre plantas e fungos. Não existe registro da enzima em células de animais (HANSON \& HAVIR, 1981). 


\subsection{A HIDROXILAÇÃO E A FORMAÇÃO DE FLAVONÓIDES E DIHIDROF LA VONÓIS}

As flavanonas naringenina e eriodictiol são produzidas como resultado da ação sequencial de enzimas hidroxilase $(\mathrm{CAH}), \mathrm{COA}$ ligase $(4-\mathrm{CL})$, sintase (CHS) e isomerase ( $\mathrm{CHI})$, a partir do ácido t-cinâmico como substrato (Figura 1).

A hidroxilação de flavanonas para dihidroflavonóis, como por exemplo: de naringenina para dihidrocampferol e de eriodictiol para dihidroquercetina, já foi demonstrado em preparações enzimáticas de flores de Mattiola incana, Antirrhinum majus e outras plantas (Forkmann et alii, 1980, citados por HANKEL-RIEGER, 1989; SCHUTTE, 1985), em reação catalisada pela enzima flavanona 3-hidroxilase.

BRITSCH et alii (1981) isolaram a flavanona 3-hidroxilase em células de salsa, através da indução pela luz ultra-violeta. Identificaram também a enzima flavonolsintase (dihidroflavonoloxidase), responsável pela reação de transformação de dihidroflavonóis para flavonóis, como por exemplo: de dihidrocampferol para campferol; de dihidroquercetina para quercetina e cianidina. (Figura 1). 
Na análise da estrutura dos compostos flavonóides, informações compreensivas acerca da espectrometria de massa (MS) foram publicadas por MABRY \& MARKHAM, 1975; MABRY \& ULUBELEN, 1980; MARKHAM, 1988 e GRAYER, 1989, entre outros. Os primeiros desenvolveram nomenclatura sistemática dos compostos por espectrometria de massa por impacto eletrónico (EI-MS), HEIDIN \& PHILLIPS (1992) aperfeiçoaram o método e registraram valores de identificação de 43 flavonas e flavonóis, 7 isoflavonas, 18 flavanonas e dihidroflavonóis, e 11 chalconas e dihidrochalcon as.

Análises quantitativas e suplementação de flavonóides e dihidroflavonóis foram feitas em flores de Dianthus caryophyllus por STICH et alii (1992), em raízes de Pongamia pinnata por TANAKA et alii (1992).

2.3 A FUNÇÃO dOS COMPOSTOS FLAVONÓIDES NA RESPOSTA AO "STRESS" FISIOLOGICO, FITOPATOLOGICO E O COMPROMETIMENTO COM O ENRAIZAMENTO.

Dentre os ap roximadamente 2000 flavonóides (HINDERER \& SEITZ, 1988) alguns podem ser produzidos e acumulados em 
células e tecidos cultivados "in vitro". Desde a década de 60 , a cultura de tecidos vem crescen do na importância de fornecer informações da biosintese de flavonóides e regulação das vias corresp ondentes.

O grande número de flavonóides é convenientemente dividido em 12 classes (HARBORNE, 1980). As estruturas químicas destes compostos encontram-se reunidas na Figura 3.

O estudo da regulação da via dos flavonóides tem colaborado na compreen são de alguns processos fisiológicos até então pouco ou em nada conhecidos (DOUGLAS, 1992)

Elliger et alii (1980), citados por BROETTO (1991), detectaram o efeito da inibição de larvas de Eliothus zea, na presença de flavonóides como eriodictiol, dihidroquercetina e DHQ-glicosídeo. Os autores revelaram ainda que as plantas são capazes de produzir diferentes tipos de compostos fenólicos, numa reação de defesa, dependendo do tipo de inseto que as atacam . 

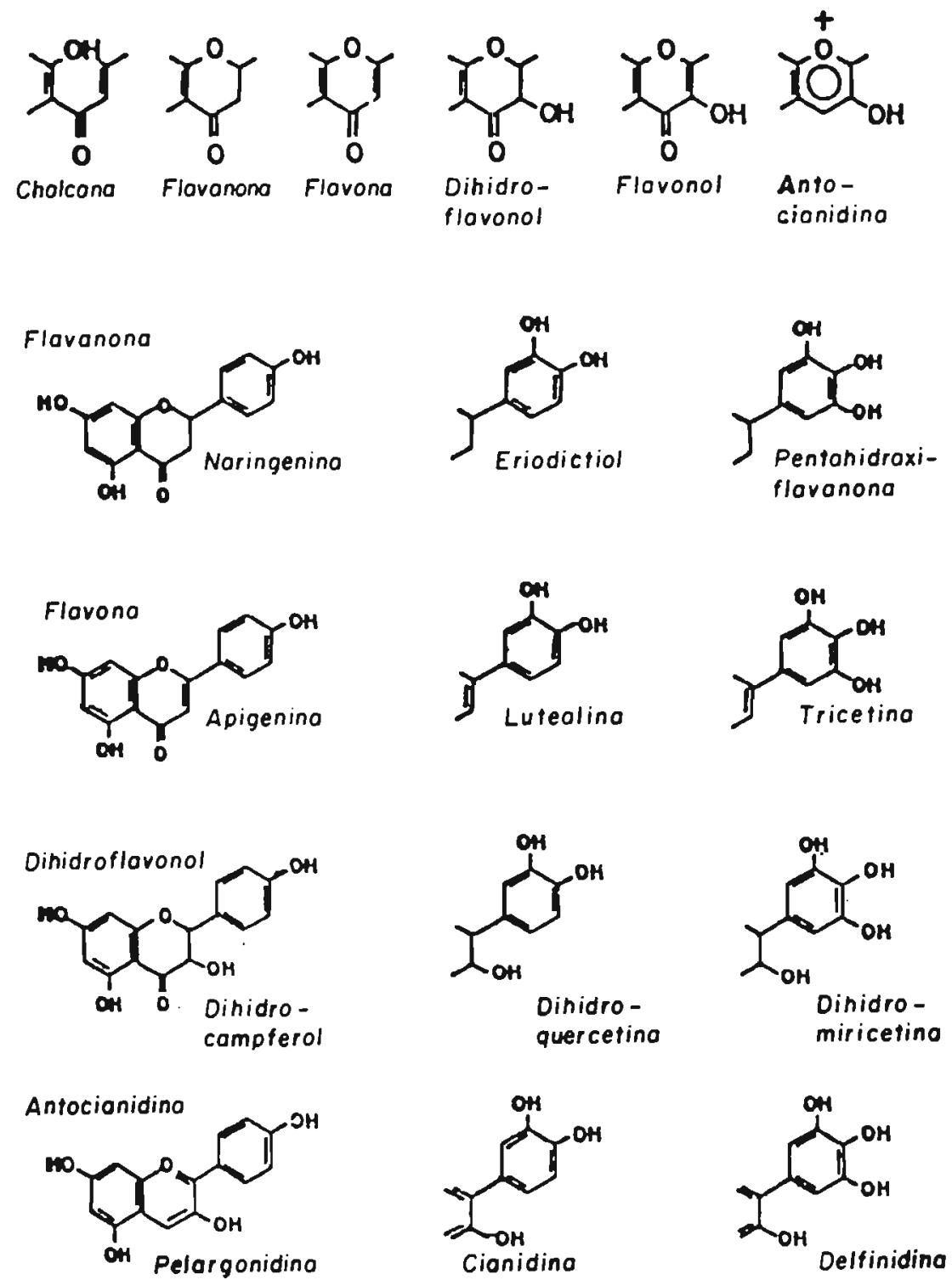

Figura 3. As principais classes dos compostos flavonóides (HINDERER \& SEITZ, 1988). 
Também contra microorganismos fitopatogênicos, há evidências da ação de defesa desencadeada pelos isoflavonóides, que agem como fitoalexinas (biocidas naturais) combaten do infecções por fungos, bactérias ou virus. (GLEITZ, 1989; DALKIN et alii, 1990; DIXON et alii, 1989; HOAGLAND, 1990; GRAHAM et alii, 1990).

REDMOND et alii (1986) descobriram ainda, a participação de flavonas na indução de expressão de genes em Rhizobium, que atuam na nodulação das plantas leguminosas.

Outra característica notável destes compostos é verificada na sua capacidade antioxidante, que funciona como "escu do protetor" das plantas contra os raios ultra-violeta (HARBORNE \& WILLIAMS, 1972; KAKEGAWA et alii, 1991; HOAGLAND, 1990). Este efeito é devido à alta capacidade de absorção das flavonas e flavonóis, que absorvem normalmente a radiação compreendida entre 330 e $350 \mathrm{~nm}$, protegendo cofatores como NAD e NADP; proteínas e ácidos nucléicos (WEISS \& HALEVY, 1991).

A excisão de partes, e o conseqüente ferimento, também induz acréscimos na atividade da PAL, em diversos órgãos e tecidos de plantas. Ésteres do ácido hidroxicinâmico (tais como 
- ácido clorogênicol são produzidos, e o mecan ismo de resposta assemelha-se ao do induzido pela ação da luz (JONES, 1984).

A habilidade dos tecidos de plantas em desenvolver raizes "in vitro", depende das interações entre os fatores exógenos e endógenos. Desde os estudos de Torrey $(1965,1976)$ e Scott (1972), citados por EVANS (1985), o papel das auxinas tornouse bem estabelecido como os principais fatores envolvidos na diferenciação e alongamento das células da raiz, bem como a formação de raízes adventicias. O mecanismo de ação destes compostos permanece controverso, apesar dos novos enfoques através da biologia molecular (BAULCOMBE et alii, 1981; HAGEN et alii, 1984; WALKER et alii, 1985; KRIEKEN et alii, 1991).

Alguns compostos orto-dihidroxifenóis específicos são tidos como cofatores do en raizamento. Produzidos nas folhas e brotos, são translocados para a região do en raizamento, on de, com auxinas e polifenoloxidases, dão origem ao complexo estimulante da diferenciação radicular. (Bauillenne, 1964 e Doud \& Carlson, 1977, citados por BAJAJ, 1986).

Alguns dos protetores de auxinas são polimeros ortodihidroxifenóis, e sua principal função é a de conservar os tecidos em estado reduzido, atuando como antioxidantes, e 
portanto, mantendo um baixo potencial redox, condição associada à juvenilidade (MCCOMB \& BENNETT, 1986).

\subsection{A MICROPROPAGAÇÃO DO EUCALIPTO E OS PROBLEMAS DO ENRAIZAMENTO DIRETO "IN VITRO".}

Com uma importância econơmica cada vez mais inquestionável, o eucalipto é hoje a principal matéria prima de importantes segmentos industriais como os de papel, madeireiro e de construção. Em todos os lugares onde foi implantada, essa árvore originária da Austrália - onde soma 600 espécies, das quais 150 com aplicação comercial - adaptou-se muito bem (LIMA, 1993).

No Brasil, em geral, as plantações de eucalipto são utilizadas principalmente para a produção de celulose, carvão, chapas duras e para a produção de lenha. As espécies de rápido crescimento podem, ainda, dar uma contribuição significativa aos programas de recuperação de áreas degradadas, assim como fornecer proteção adequada a área críticas, tais como na estabilização de dunas, no controle da erosão, no funcionamento harmo̊nico das microbacias hidrográficas, na recuperação de áreas de mineração, como queb ra-ventos, etc. (LIMA et alii, 1990). 
De grande potencial produtivo, o E. grandis, é provavelmente a espécie de eucalipto mais plantada do gênero, especialmente para a produção de madeira como matéria-prima para fins industriais. A estimativa muridial da área total de plantações de E. yrandis é de aproximadamente 1 milhão de hectares. A estratégia atual de melhoramento florestal que resulta em ganhos consideráveis, embora também com riscos consideráveis, é através da seleção clonal, pela qual se procura maximizar os ganhos em uma única geração. (Ferreira, 1983, citado por LIMA, 1993).

A propagação vegetativa das plantas lenhosas se processa, rotineiramente, pela estaquia dos ramos. Com o desenvolvimento da técnica de microp ropagação de plantas, ampliaram-se as perspectivas de obtenção de material de melhor qualidade agronómica em qualquer época do ano, em espaço e tempo reduzidos, e com o máximo aproveitamento do propágulo vegetal, às vezes escasso em coleção de germoplasma (BARBOSA et alii, 1992).

O efeito mais notável da microp ropagação relaciona-se à reversão da juvenilidade. As plantas obtidas "in vitro", por cultura de meristema, podem apresentar desenvolvimento semelhante às plântulas que são provenientes da propagação 
por sementes (HOWARD, 1990; BLOMSTEDT, 1991; SARAVITZ et alii, 1991).

As maiores limitações da micropropagação de eucalipto, e outras plantas lenhosas, são os problemas de esterilização do material provindo de árvores desenvolvidas no campo e o enraizamento direto de partes aéreas "in vitro" (DOLCETSANJUAN et alii, 1990; SERRES et alii, 1990; KRIEKEN et alii, 1991; ARJONA et alii, 1990). Permanece difícil a indução de formação de parte aérea, ou embrióides, a partir de "calos" (aglomerado de células não diferenciadas) originados de árvores adultas, mas isso é de menor importância prática que os dois primeiros problemas (NANDWANI \& RAMAWAT, 1991; ROY \& $D E, 1990)$.

Para uma microp ropagação bem sucedida, três dificuldades principais precisam ser vencidas: (a) estabelecimento de explantes primários em cultura; (b) desenvolvimento do meio de cultura ideal e condições ambientais que proporcionem altas taxas de multiplicação e (c) indução do en raizamento. Embora considerável progresso tenha sido conseguido com relação aos dois primeiros itens. o en raizamento permanece o principal problema na propagação de árvores "in vitro" (BAJAJ, 1986; VIETEZ et alii, 1989; ABDULLAH et alii, 1989). 


\section{MATERIAL E MÉTODOS}

A parte experimental deste trabalho foi conduzida em Piracicaba, SP, nos Laboratórios do Centro de Biotecnologia Agrícola (CEBTEC), Escola Superior e Fundação de Estudos Agrários "Luiz de Queiróz" - Universidade de São Paulo (FEALQ/ ESALQ - USP), no periodo de agosto de 1990 a dezembro de 1992. 


\subsection{PLANTAS MATRIZES}

Neste trabalho, foram utilizados clones das matrizes GO 250; GO 669 e GO 682 de Eucalyptus grandis Hill ex Maiden, selecionados no CEBTEC.

\subsection{OBTENÇÃO E DESINFECÇÃO DOS EXPLANTES}

Das matrizes selecionadas, foram coletados ramos de aproximadamente $15 \mathrm{~cm}$ de comprimento, e imediatamente colocados em água e transferidos para os laboratórios do CEBTEC, on de foram lavados em água corren te e retiradas suas fol has.

Após o desfol hamento, os ramos foram tratados com solução do fungicida benomyl (concentração de $300 \mathrm{mg} / \mathrm{l}$ ), autoclavada e acrescida do antibiótico kasugamicina (concentração de 4 $\mathrm{ml} / \mathrm{l})$, durante 15 horas.

Desses ramos, segmentos nodais $(1,0$ a $1,5 \mathrm{~cm}$ de comprimento), contendo uma única gema axilar, foram cortados 
e mantidos na mesma solução fungicida/antibiótico descrita, por tempo de 4 horas, em agitação.

A seguir, sob condições assépticas, em câmara de fluxo laminar, os explantes foram imersos em solução de hipoclorito de sódio (concentração final de $1 \%$ de cloro ativo), acrescida de uma gota de detergente não iónico e mantidos durante 20 minutos em agitação. Seguiu-se lavagem do material (3 a 4 vezes) em água deionizada estéril.

3.3 INOCULAÇÃO E MICROPROPAGAĢÃO DAS GEMAS EPICÓRMICAS: MEIOS DE CULTURA, CONDIÇÕES AMBIENTAIS, PROCEDIMENTOS E AVALIAÇÃO

- meio de cultura básico, utilizado durante toda a pesquisa, foi o de GONÇALVES (1980), modificado apenas no tipo e quantidade dos reguladores de crescimento, conforme as diferentes fases de diferenciação e crescimento das plantas (quebra de dormência da gema epicórmica; estabelecimento das brotações; microp ropagação; alongamento e en raizamento das gemas). Fizeram parte da constituição básica do meio, os componentes inorgânicos relacionados no QUADRO 1. 
Quadro 1 Sais de GONÇALVES (1980) modificados (SGM)- Meio de Cultura Básico

\begin{tabular}{|c|c|c|}
\hline $\begin{array}{c}\text { Número de } \\
\text { Solução }\end{array}$ & Sal & $\begin{array}{c}\text { Con cen tração } \\
\mathrm{mg} / \mathrm{l}\end{array}$ \\
\hline \multicolumn{3}{|c|}{ MACRONUTRIENTES } \\
\hline 1 & $\mathrm{NH}_{4} \mathrm{NO}_{3}$ & 800 \\
\hline 2 & $\mathrm{KNO}_{3}$ & 1000 \\
\hline 3 & $\mathrm{KH}_{2} \mathrm{PO}_{4}$ & 170 \\
\hline 4 & $\mathrm{Ca}\left(\mathrm{NO}_{3}\right)_{2} \cdot 4 \cdot \mathrm{H}_{2} \mathrm{O}$ & 236 \\
\hline 5 & $\mathrm{MgSO}_{4} \cdot 7 \cdot \mathrm{H}_{2} \mathrm{O}$ & 250 \\
\hline \multicolumn{3}{|c|}{ MICRONUTRIENTES } \\
\hline \multirow[t]{2}{*}{6} & $\mathrm{FeSO}_{4} \cdot 7 \cdot \mathrm{H}_{2} \mathrm{O}$ & 37,3 \\
\hline & $\mathrm{Na}_{2} \mathrm{EDTA}$ & 27,8 \\
\hline \multirow[t]{7}{*}{7} & $\mathrm{H}_{3} \mathrm{BO}_{3}$ & 6,2 \\
\hline & $\mathrm{CoCl}_{2} \cdot 6 \mathrm{H}_{2} \mathrm{O}$ & 0,25 \\
\hline & $\mathrm{CuSO}{ }_{4} \cdot 5 \mathrm{H}_{2} \mathrm{O}$ & 0,025 \\
\hline & $\mathrm{MnSO} 4 \cdot \mathrm{H}_{2} \mathrm{O}$ & 1,7 \\
\hline & $\mathrm{MOO}_{3}$ & 0,144 \\
\hline & $\mathrm{Zn} \mathrm{SO} 4 \cdot 7 \mathrm{H}_{2} \mathrm{O}$ & 3,0 \\
\hline & $\mathrm{KI}$ & 0,75 \\
\hline
\end{tabular}


A sacarose, utilizada como fonte de carbono, os complementos vitaminicos (complexo B), e demais substâncias orgânicas, são indicadas no QUADRO 2.

Quadro 2. Componentes Orgânicos-Meio de Cultura Básico, segundo GONÇALVES (1980)

\begin{tabular}{clc} 
Número & \multicolumn{1}{c}{ Aditivo Orgânico } & Quantidade $\mathbf{m g} / \mathbf{l}$ \\
\hline 1 & Sacarose & 30,0 \\
2 & Tiamina & 5,0 \\
3 & Piridoxina & 0,5 \\
4 & Ácido Nicotinico & 0,5 \\
5 & Pantotenato de Cálcio & 1,0 \\
6 & Mio inositol & 100,0 \\
\end{tabular}

O estímulo à diferenciação e estabelecimento das gemas epicórmicas, foi dado pelo suprimento exógeno da auxina ácido indolilacético (A|A), na concentração de $0,5 \mathrm{mg} / \mathrm{l}$, e a cinetina benzilaminopurina (BAP), na mesma concentração.

$\mathrm{O} p H$ do meio foi ajustado para $5,7 \pm 0,1$, utilizando-se $\mathrm{NaOH}$ ou $\mathrm{HCl}$ a $0,1 \mathrm{~N}$, e depois adicionado agar $(7 \mathrm{~g} / 1)$, para solid ificação. 
- meio de cultura, assim elaborado, foi então dispensado em frascos redondos $(300 \mathrm{ml})$, num volume de aproximadamente $50 \mathrm{ml} /$ cada, com cobertura e fechamento com papel aluminio. Os frascos, contendo o meio foram esterilizados em autoclave, à temperatura de $120^{\circ} \mathrm{C}$, sob pressão de 1 atmosfera, por um período de 30 minutos.

A operação de inoculação foi realizada sob con dições assépticas, em câmara de fluxo laminar, com auxílio de pinça anatomica, previamente esterilizada por autoclavagem e flam bagem.

Dessa forma, foram estabelecidas culturas estoque, como fonte para multiplicação das gemas, em subcultivos posteriores.

Para as operações de subcultivo, foi empregado o Meio Básico de GONÇALVES (1980), contendo a cinetina benzilaminopurina, na concentração de $0,2 \mathrm{mg} / \mathrm{l}$. Os demais componentes permaneceram conforme descrito.

As operações de subcultivo para micropropagação das gemas foram conduzidas nas mesmas con dições assép ticas em câmara de fluxo laminar, on de foram dissecadas as brotações epicórmicas, com auxílio de bisturi e pinça anatómica, previamente esterilizados por autoclavagem e flambagem. As 
brotações foram repicadas ao medirem, ap roximadamente, $0,5 \mathrm{~cm}$ de comprimento.

Os explantes constituidos de tufos de cinco brotações, medindo cerca de $0,5 \mathrm{~cm}$ de comprimento, foram adotados como padrão para as sucessivas transferências, realizadas a intervalos de um mês.

A temperatura da sala de crescimento foi mantida em $24^{\circ} \mathrm{C}$ \pm 1 , ficando as culturas submetidas a um fotoperiodo de 12 horas e iluminância de ap roximadamente 900 lux.

O comportamento dos 3 diferentes clones (GO 250, GO 669 e GO 682), na fase de multiplicação, foi avaliado através do acompanhamento das taxas de multiplicação das brotações epicórmicas, tomadas durante 4 transferências sucessivas, em meio de cultura indutor da micropropagação de gemas. Foram ainda, descritos os comportamentos anat8́mico-fisiológicos, e fotografados os resultados, de cada clone. 
3.4 ALONGAMENTO DAS GEMAS MICROPROPAGADAS: MEIO DE CULTURA, CONDIÇÕES AMBIENTAIS, PROCEDIMENTOS E AVALIAÇÕES

O meio de cultura empregado, aprovado depois de diversos testes preliminares, foi o básico de GONÇALVES (1980), descrito no item anterior, suplementado com $0,05 \mathrm{mg} / \mathrm{l}$ de benzilaminopurina (BAP) e $0,05 \mathrm{mg} / \mathrm{de}$ ácido indolilbutírico (A|B), na presen ça e ausência de carvão ativado.

Os procedimentos subsequentes, como ajustagem do pH; solidificação; distribuição e esterilização do meio de cultura, foram realizados como descrito no item anterior.

Os explantes de cada clone, obtidos na última transferência, foram inoculados nas mesmas con dições assépticas, e mantidas as mesmas con dições ambientais.

Gemas alongadas, com comprimento superior a $1 \mathrm{~cm}$, foram consideradas como padrão e selecionadas para a etapa posterior, a indução de enraizamento. 
O comportamento dos 3 clones (GO 250; GO 669 e GO 682), quanto ao alongamento das gemas, foi avaliado através da obtenção da freqüência de culturas que apresentaram brotações alongadas, no final de um periodo de 4 meses, com renovações do meio de cultura, por 4 subcultivos consecutivos. Foram também, descritos os comportamentos anatỏmicofisiológicos, e fotografados os resultados, de cada clone.

3.5 INFLUENCIA DO SUPRIMENTO DE AUXINA EXOGENA (AIB) NO ENRAIZAMENTO "IN VITRO- DAS GEMAS ALONGADAS

Nesta etapa da pesquisa, toi conduzida experimentação exploratória do en raizamento de brotações alongadas (> $1 \mathrm{~cm}$ de altura) dos 3 clones (GO 250; GO 669 e GO 682), colocados em meio de cultura básico, formulado por GONÇALVES (1980), descrito no item 3.3., e suplementado com ácido indolilbutírico (A|B), na ausência de carvão ativado, e dispensado em tubos de ensaio ( $25 \times 150 \mathrm{~mm})$, na quantidade de ap roximadamente 20 ml/unidade, com cobertura e fechamento em papel alumínio.

o experimento foi constituido de cinco concentrações de AlB e 100 repetições de cada clone, sendo cada tubo de ensaio uma unidade experimental. As concentrações testadas foram as 
seguintes: 0,$0 ; 0,1 ; 0,5 ; 1,0$ e $1,5 \mathrm{mg} / \mathrm{I}$ de $A / B$, constituindo os tratamentos T1; T2; T3; T4 e T5, respectivamente. As con dições ambientais permaneceram as mesmas das fases anteriores: fotoperiodo de 12 horas, iluminância de 900 lux e temperatura de $24^{\circ} \mathrm{C} \pm 1$.

3.5.1 Avaliação da frequência do enraizamento "in vitro"

O en raizamento foi avaliado no final de 30 dias de cultura, observando-se a porcentagem de gemas que apresentaram início da diferenciação em sistema radicular.

Para efeito de comparação dos 3 clones, quanto ao comportamento "in vitro", foram obtidos também, as massas de matéria fresca e seca em estufa, das plantas que en raizaram e daquelas que não apresentaram qualquer diferenciação na região radicular; isto dentro de cada tratamento e clone. Foram feitas coletas de 15 repetições de cada grupo, com exceção do $\mathrm{T} 1$, onde as poucas plantas que enraizaram foram reservadas para os ensaios bioquímicos subsequentes. As médias dos valores obtidos foram comparadas através de histogramas. 
Foram descritos os comportamentos anatômicos-fisiológicos, diferenciados dos 3 clones empregados, no momento do en raizamento; e ainda, fotografados os resultados obtidos.

3.5.2 Obtenção dos extratos de plantas e preparo das amost ras

As plantas que enraizaram e as que não apresentaram qualquer diferenciação na região da raiz, foram separadas em dois grupos, dentro de cada tratamento (T1, T2, T3, T4 e T5) e clone (GO 250; GO 669 e GO 682). De cada grupo foram coletados 5 repetições para ensaios bioquímicos posteriores.

A metodologia de extração, a partir de tecidos diferenciados de plantas, foi adaptada de WONG et alii (1974) e MESSNER et alii (1991).

Cerca de $200 \mathrm{mg}$ de material da planta, recém coletada e lavada, foi triturada e homogeneizada em almofariz de porcelana, com $2 \mathrm{ml}$ de tampão borato-HCl $25 \mathrm{mM}$ frio, $\mathrm{pH} \mathrm{8,8}$, e $\beta$-mercap toetanol $10 \mathrm{mM}$. O homogenado foi centrifugado a $10.000 \mathrm{~g}$, por $15 \mathrm{~min}$. O sobrenadante, verde-amarelo claro, foi usado nos ensaios subsequentes da determinação do teor 
protéico e atividade enzimática da fenilalanina amónia-liase (PAL) e glucose-6-f osfato-desidrogen ase (G-6P-DH).

\subsubsection{Determinação do teor de proteína}

A determinação foi feita pelo reagente de Folin-Ciocalteau, segundo LOWRY et alii (1951).

\section{REAGENTES:}

1. Reativo de Tartarato Alcalino. Foram dissolvidos $20 \mathrm{~g}$ de $\mathrm{Na}_{2} \mathrm{CO}_{3}$ e $0,5 \mathrm{~g}$ de tartarato de sódio em 1 litro de $\mathrm{NAOH}$ $0,1 N$.

2. Solução de $\mathrm{Cu} \mathrm{SO} \mathrm{S}_{4} \cdot 5 \mathrm{H}_{2} \mathrm{O}, 0,1 \%$.

3. Beagente cúprico alcalino. Foram misturados $45 \mathrm{ml}$ do reativo 1 e $5 \mathrm{ml}$ do reativo 2. O preparo foi feito no dia do uso.

4. Reagente de Folin-ciocalteau.

Tungstato de sódio . $2 \mathrm{H}_{2} \mathrm{O} \ldots 100 \mathrm{~g}$

Molibdato de sódio . $2 \mathrm{H}_{2} \mathrm{O} \ldots . .25 \mathrm{~g}$

Dissolvidos em $700 \mathrm{ml}$ de água destilada e adicionados: 
Ácido fosfórico xaroposo a $85 \% \ldots 50 \mathrm{ml}$
Ácido clorídrico concentrado $\ldots \ldots 100 \mathrm{ml}$

A solução foi colocada em balão munido de condensador de refluxo e aquecida durante 10 horas. Depois de fria, foram adicionados:

Sulfato de lítio ..... $150 \mathrm{~g}$

Água destilada ..... $50 \mathrm{ml}$

Água bromada ..... gotas até ficar com a cor amareloou ro

Iécnica: Foi colocado $0,1 \mathrm{ml}$ da amostra, contendo cerca de $100 \mu \mathrm{gg}$ de proteina, num tubo com $2 \mathrm{ml}$ do reagente 3 , misturando rapidamente. Depois de 10 minutos foi adicionado 1 $\mathrm{ml}$ do reagente 4. A densidade ótica foi lida em espectrofótometro a $650 \mathrm{~nm}$, após um periodo de 60 minutos. Como a cor não é estritamente proporcional à concentração (somente de 100 a $300 \mu g$ ), foi preparada uma curva padrão com ASB (Albumina de Soro Bovino), nos limites das concentrações comparadas.

A quantidade de proteína na amostra foi expressa em $\mathrm{mg} / \mathrm{ml}$ de extrato. Os clones (GO 250; GO 669 e $G O \quad 682$ ) puderam ser comparados entre si, com relação ao teor protéico, através da elaboração de histograma. 
3.5.4 Análise da atividade enzimática da Fenilalanina Amón ia-liase (PAL)

O ensaio da atividade da fenilalanina amónia-liase foi realizado a partir dos extratos enzimáticos brutos (item 3.5.2) das plantas que apresentaram, ou não, diferenciação do sistema radicular. A enzima, que catalisa a reação de desaminação da fenilalanina, produzindo ácido t-cinâmico, teve o seu produto quantificado por método espectrofotométrico a $290 \mathrm{~nm}$, na presença de L-fenilalanina, após incubação em banho de água, na temperatura constante de $30^{\circ} \mathrm{C}$, por um período de 15 minutos. A técnica foi elaborada com base nos trabalhos de WONG et alii (1974) e MESSNER et alii (1991).

A reação enzimática ocorreu na presença de 0,1 a $0,3 \mathrm{ml}$ de extrato enzimático $(0,90$ a $1,40 \mathrm{mg} / \mathrm{ml}$ de proteína); 100 umoles de tampão-borato $(\mathrm{pH} 8,8) ; 1,5$ umoles de mercaptoetanol e 15 umoles de L-fenilalanina (substrato). Com volume final de $3 \mathrm{ml}$, e após o tempo de incubação, a mistura de reação foi transferida para cubetas de quartzo próprias para leitura em espectrof otómetro. Foram preparadas 5 amost ras de cada grupo, com um número de 3 duplicatas/amostra. Amostras elaboradas, com ausência do substrato L-fenilalanina, foram utilizadas como controle da análise. 
A atividade enzimática $(Z)$ da $\mathrm{PAL}$, em $\mathrm{Kat} \cdot \mathrm{Kg}^{-1}$ proteína, foi calculada pela fórmula:

$$
\begin{aligned}
& \mathrm{Z}\left[\text { Kat. } \mathrm{Kg}^{-} \text {prot } .\right]=\frac{\Delta E}{\mathrm{t}(\mathrm{s})} \cdot \frac{V(\mathrm{ml})}{\mathrm{d}(\mathrm{cm}) \cdot \varepsilon_{290}} \cdot \frac{10^{9}}{[\operatorname{Prot} \cdot(\mu \mathrm{g})]} \\
& \text { on de: } \mathrm{Kat}=\mathrm{mol} / \mathrm{s} \\
& \Delta E=\text { variação da extinção molar } \\
& \varepsilon_{290}=\text { coeficiente de extinção molar }\left(10 \frac{\mathrm{cm}^{2}}{\mathrm{~mol} \cdot 10^{6}}\right) \\
& \mathrm{d}=\text { distância atravessad a pela luz } \\
& V=\text { volume final da reação } \\
& t=\text { tempo da reação. }
\end{aligned}
$$

3.5.5 Análise da atividade enzimática da Glucose-6Fosfato-Desidrogen ase (G-6P-DH)

O en saio da atividade da glucose-6-f osfato-desidrogenase foi realizado a partir dos extratos enzimáticos brutos (item 3.5.2.) das plantas que ap resentaram, ou não, diferenciação do sistema radicular, quan do da passag em pelo meio indutor do en raizamento. A enzima catalisa a reação de desidrogenação da glucose-6-fosfato, produzindo glucono- $\delta$-lactona 6-P e reduzindo NADP em NADPH. 
Glucose-6-P $\frac{\text { desidrogenase }}{\substack{\mathrm{NADP}^{+} \\ \mathrm{Mg}^{++}}}>$glucono- $\delta-$ lactona 6-P +NADPH. $\mathrm{H}^{+}$

A atividade enzimática da $G-6 P-D H$ foi determinada pelo coeficiente da extinção molar da reação da redução do NADP em NADPH (ABSOLOM, 1986; BERGMAYER, 1975).

Em cubetas de quartzo, contendo um volume final de $3 \mathrm{ml}$, a reação enzimática ocorreu na presença de $2590 \mu$ l de tampão tris $-\mathrm{HCl} \quad 0,1 \mathrm{M}(\mathrm{pH} \quad 7,6) ; 200 \mu \mathrm{l}$ de $\mathrm{MgCl}_{2} 0,1 \quad \mathrm{M} ; 100 \mu \mathrm{l}$ de glucose-6-f osfato $35 \mathrm{mM}$ e $10 \mu l$ do extrato enzimático.

Depois de curto período em agitação, a reação foi iniciada pela adição de $100 \mu l$ de NADP 11 mM, sendo a extinção monitorada espectrofotometricamente a $340 \mathrm{~nm}$. Foram preparadas 5 amostras de cada grupo com um número de 3 duplicatas/amostra. Amostras elaboradas, com ausência da glucose-6-fosfato, foram utilizadas como controle da análise.

A atividade enzimática (Z) da G-6P-DH, em Kat• $\mathrm{Kg}^{-1}$ prot., foi calculada pela fórmula:

$\mathrm{Z}\left[\right.$ Kat. $\mathrm{Kg}^{-}$prot.$]=\frac{\Delta E}{\mathrm{t}(\mathrm{s})} \cdot \frac{\mathrm{V}(\mathrm{ml})}{\mathrm{d}(\mathrm{cm}) \cdot \varepsilon_{340}} \cdot \frac{10^{9}}{[\operatorname{Prot} \cdot(\mu \mathrm{g})]}$ 
onde: $\quad$ Kat $=\mathrm{mol} / \mathrm{s}$

$\Delta E=$ variação da extinção molar

$\varepsilon_{340}=$ coeficiente de extinção molar $\left(6,22 \frac{\mathrm{cm}^{2}}{\mathrm{~mol} \cdot 10^{\circ}}\right)$

d = distância atravessad a pela luz

$V=$ volume final da reação

$t=$ tempo da reação 


\section{RESULTADOS E DISCUSBÃO}

\subsection{TAXA DE MULTIPLIẼAÇĀO DAS BROTAÇÕES EPICORMICAS}

Wuanto à taxa de multiplicação das brotações epicórmicas, acompanhada nos três clones (GO 250; GO 669 e GO 682) de Eucalyptus grandis Hill ex Maiden, durante 4 subcultivos sucessivos, pode-se verificar, pela Figura 4, que, para os clones GO 669 e GO 682, o processo de multiplicação ocorreu no primeiro subcultivo com os dois clones apresentando taxas de multiplicação bem próximas, $2,0: 1$ e 1,8:1, respectivamente. A partir do terceiro subcultivo, a diferença de ambos com relação ao clone GO 250 começou a acentuar-se (12,2:1 e 10,6:1 para $6,0: 1)$. No quarto subcultivo, a diferença tornou-se mais 
evidente, quando as taxas de multiplicação passaram a $30,4: 1$ e 26,8:1 nos dois primeiros, e 14,2:1 no clone GO 250.

Os explantes constituidos de tufos de cinco brotações, medindo cerca de $0,5 \mathrm{~cm}$ de comprimento, foram adotados como padrão, e considerados como 1 unidade de multiplicação. 


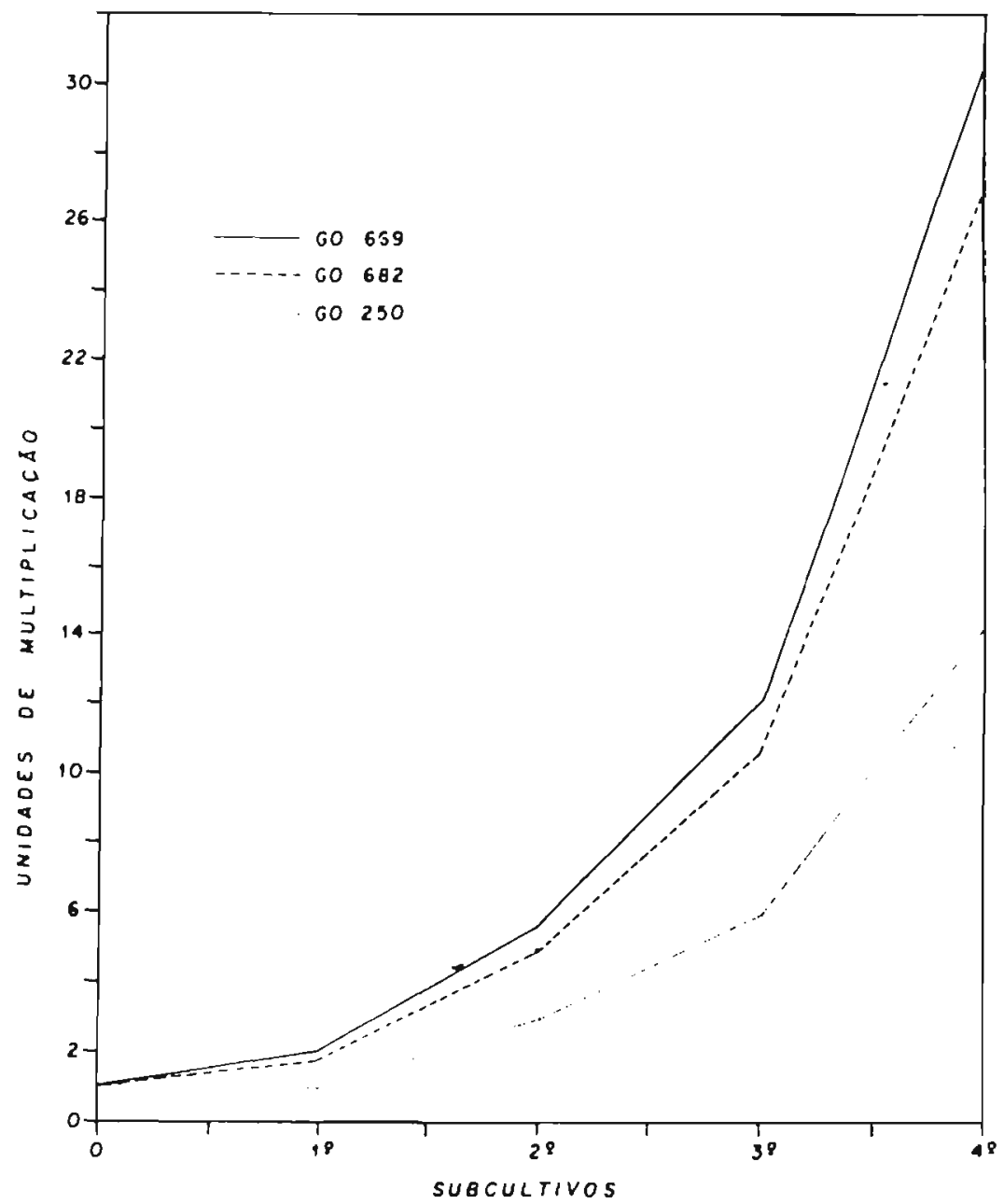

Figura 4. Evolução das brotações epicórmicas produzidas, pelos explantes iniciais (tufo de 5 brotações) dos clones GO 669; GO 682 e GO 250, durante 4 subcultivos sucessivos, em meio básico suplementado com $0,2 \mathrm{mg} / \mathrm{I}$ de BAP. 
O clone GO 669 foi o que apresentou melhores taxas de multiplicação de gemas "in vitro", que se mostraram vigorosas e de maiores tamanhos (maiores que $0,5 \mathrm{~cm}$ de altura). 0 clone GO 682 teve comportamento não muito diferenciado, em relação às taxas de multiplicação, mas apresentou gemas menores, de tamanho pequeno a médio (entre 0,3 e $0,5 \mathrm{~cm}$ de comprimento) e de coloração mais avermelhada. Com baixas taxas de multiplicação, o clone GO 250, apresentou gemas pequenas (menores que $0,3 \mathrm{~cm}$ de comprimento), e ainda, maior susceptibilidade à contaminação por fungos exógenos e bactérias endógenas.

As Figuras 5, 6 e 7 ap resentam gemas dos clones GO 250; GO 669 e GO 682, multiplicadas em meio de cultura básico de GONÇALVES (1980), suplementado com $0,2 \mathrm{mg} / 1$ de AlB.

Tais resultados evidenciam que os clones apresentaram variações entre si, observações estas já descritas por SILVA (1990) e GROTHGE (1992) em clones de Eucalyptus grandis Hill ex Maiden. A diferenciação no comportamento de clones, foi também observada por GONÇALVES (1982) na micropropagação de Eucalyptus urophylla S.T. Blake "in vitro".

Pode-se verificar, ainda, que $o$ fato de as culturas originadas dos clones GO 669 e GO 682 terem se multiplicado 
em taxas significativas, a partir do segundo subcultivo, é uma boa indicação da viabilidade de utilização das brotações epicórmicas, como explantes, na propagação clonal "in vitro" de árvores adultas de E. grandis, conforme citado por IKEMORI (1987).

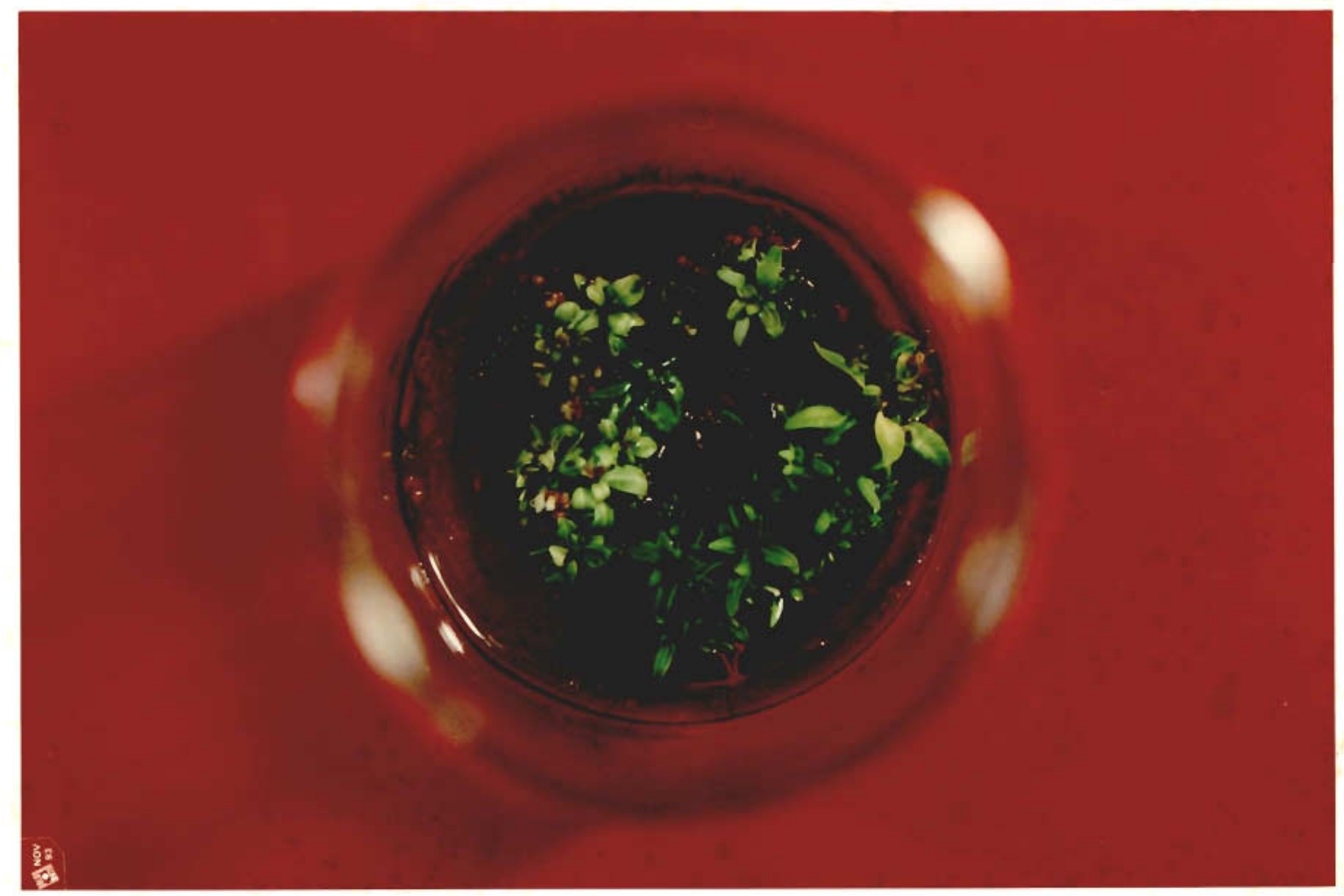

Figuras 5. Multiplicação "in vitro" de gemas do clone Go 250, de Eucalyptus grandis Hill ex Maiden. 

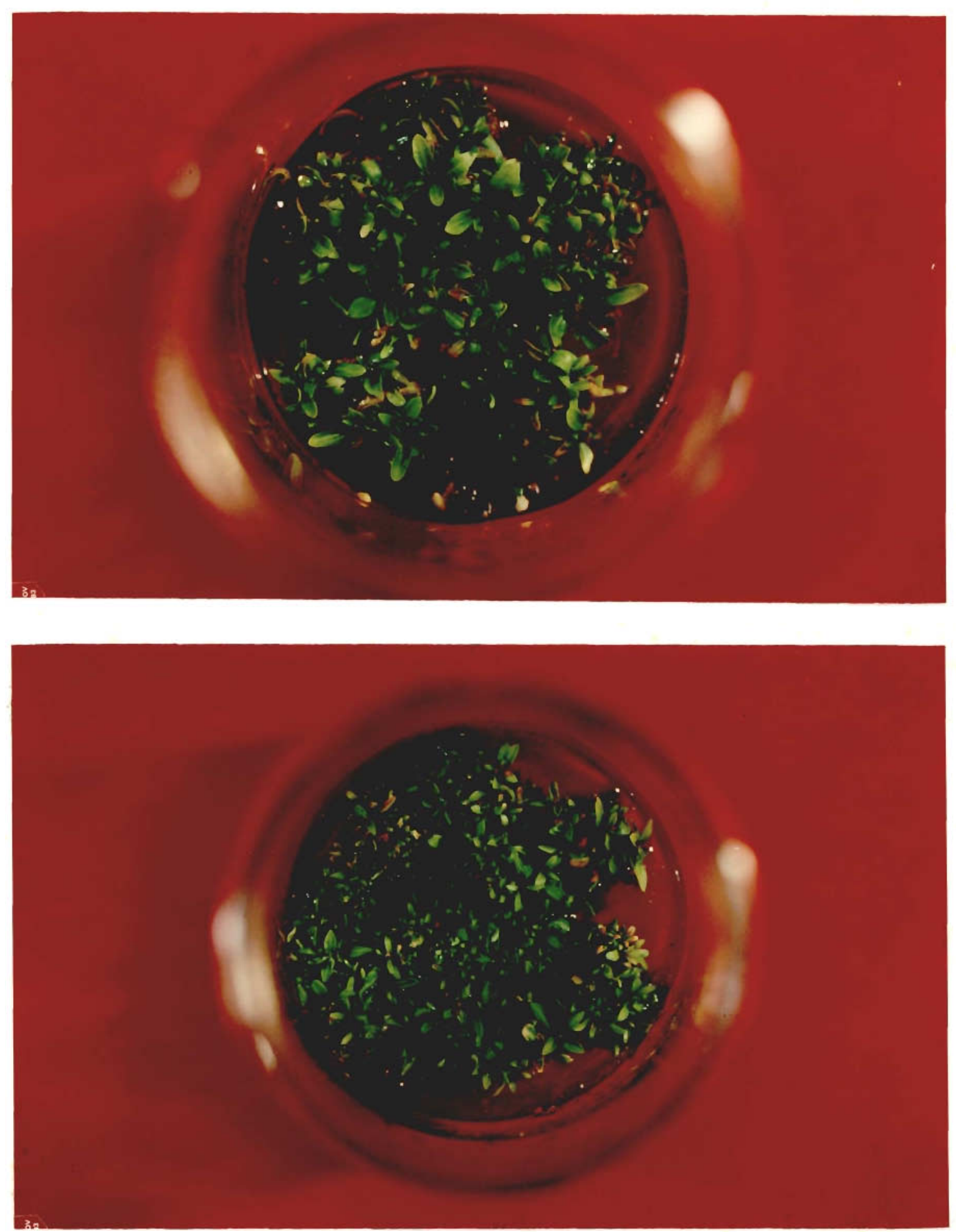

Figura 6 e 7. Multiplicação "in vitro" de gemas dos clones GO 669 (superior) e GO 682 (inferior), de Eucalyptus grandis Hill ex Maiden. 
4.2 FREQÚẼ NCIA DE ALONGAMENTO DAS GEMAS MICROPROPAGADAS

O comportamento dos 3 clones (GO 250; GO 669 e GO 682), quanto ao alongamento das gemas, pode ser resumido no Quadro 3, tendo sido utilizado 0 meio de cultura de GONÇALVES (1980), suplementado com $0,05 \mathrm{mg} / \mathrm{l}$ de BAP e 0,05 $\mathrm{mg} / \mathrm{l}$ de AlB, durante 4 subcultivos sucessivos, a intervalos regulares de 1 mês.

Quadro 3. Freqūência de culturas com brotações alongadas (1) dos clones GO 250; GO 669 e GO 682, em meio de cultura básico de GONÇALVES (1980), suplementado com $0,05 \mathrm{mg} / /$ de BAP e $0.05 \mathrm{mg} / / \mathrm{de}$ AlB

GO 250

40

GO 669

75

GO 682

63

(1) Consideraram-se, como brotações alongadas, aquelas com alturas superiores a $1 \mathrm{~cm}$. 
Como gemas alongadas, foram consideradas aquelas com alturas superiores a $1 \mathrm{~cm}$, as quais foram também selecionadas para a etapa posterior de en raizamento.

Nesta fase, os clones comportaram-se diferentemente, um em relação ao outro, e de maneira concordante com a fase anterior de multiplicação de gemas, onde os clones GO 669; GO 682 e GO 250 se sucederam por ordem de maior vigor. Foram também observados "calos", aglomerados de células não diferenciadas, nas bases das folhas dos clones GO 250 e GO 682. Quanto à oxidação, a maior incidência ocorreu no clone GO 669, tendo sido insignificante nos demais.

As Figuras 8,9 e 10 apresentam gemas alongadas dos clones GO 250; GO 669 e GO 682, cultivadas em meio de cultura de GONÇALVES (1980), e modificado com suplemento de 0,05 $\mathrm{mg} / \mathrm{l}$ de BAP e $0,05 \mathrm{mg} / 1 \mathrm{de}$ AlB.

Os efeitos obtidos, referentes à atuação do AlB e BAP, na elongação das gemas, estão coerentes com a literatura consultada (ZIMMERMAN \& MILLER, 1991; BARBOSA, 1992; SILVA, 1992). Altas taxas de elongação foram conseguidas modificando-se o meio de cultura pela elevação, em cinco vezes, do suprimento de auxina e cinetina exógenos. 

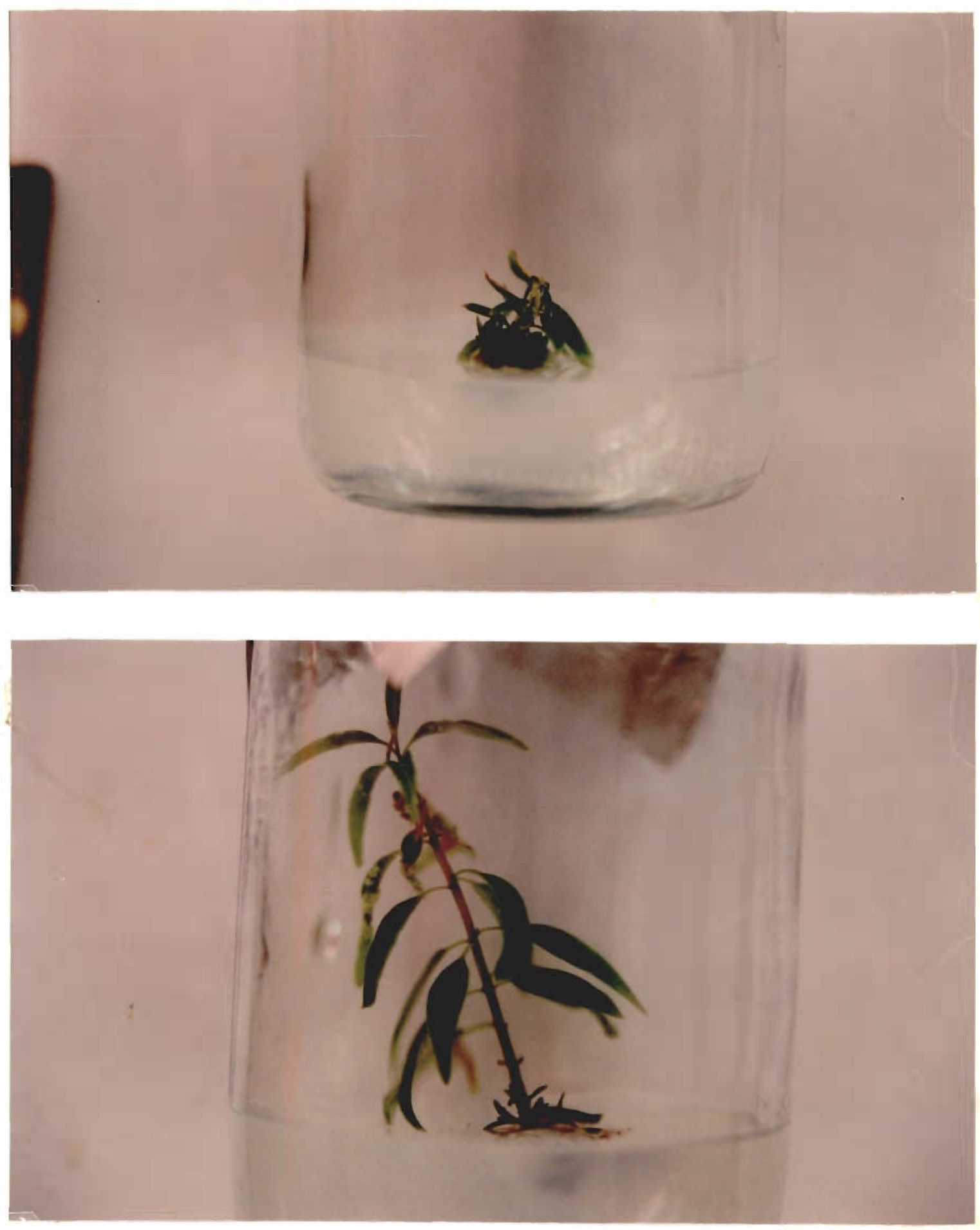

Figuras 8 e 9 . Alongamento de gemas dos clones 60250 (superior) e GO 669 (inferior), de Eucalyptus grandis Hill ex Maiden, "in vitro" 


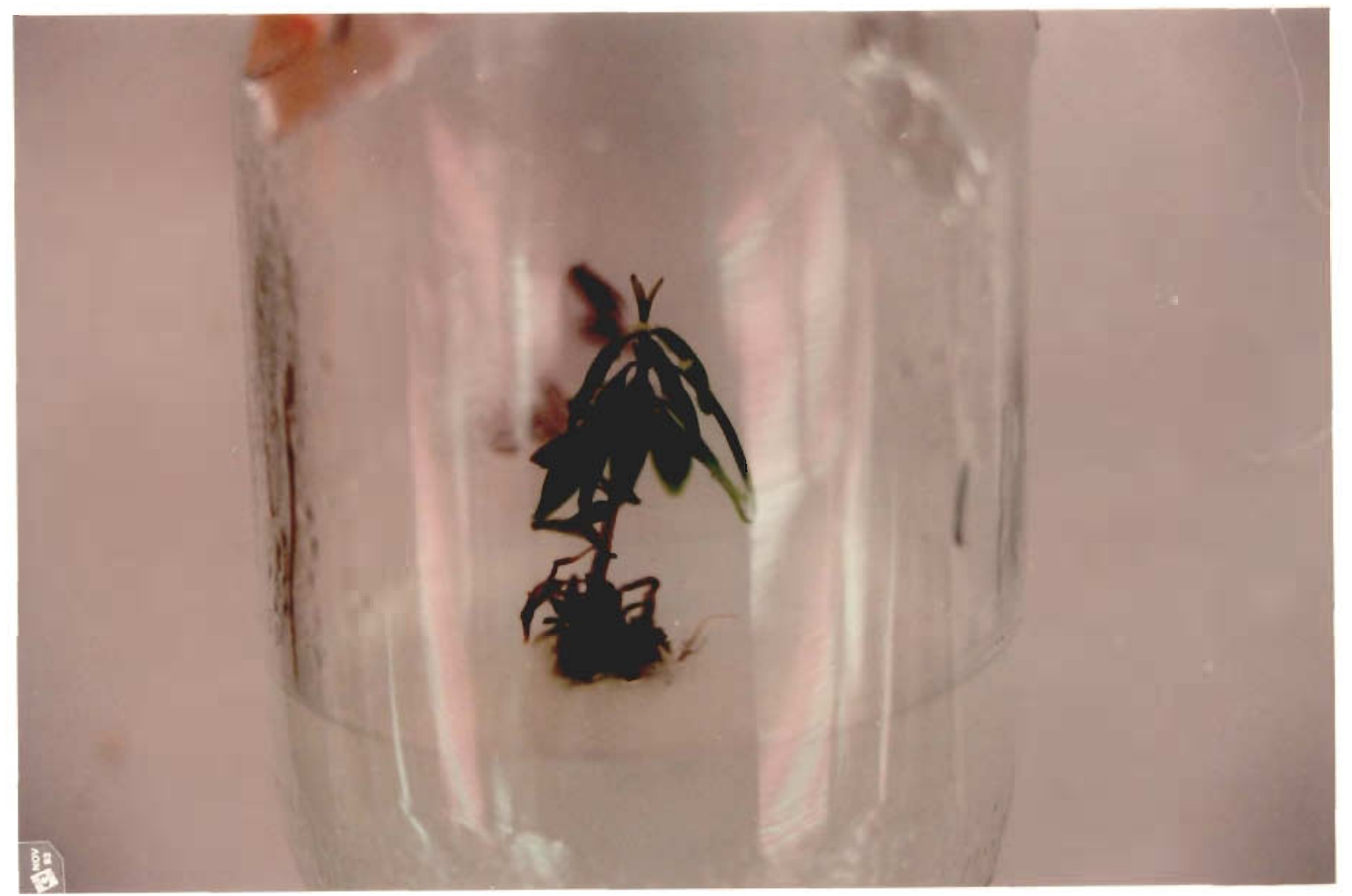

Figura 10. Alongamento de gemas do clone GO 682 de Eucalyptus grandis Hill ex Maiden, "in vitro" 
Nesta fase da pesquisa, foi conseguida a associação do alongamento e multiplicação satisfatória de brotações epicórmicas cultivadas "in vitro" dos clones Go 682 e Go 669. O clone GO 250, em exceção, apresentou baixa taxa de elongação (40\%) e folhas de má qualidade, pequenas e de limbo recu rvado; havendo necessidade de melhoramento do aspecto morfológico dessas brotações.

\subsection{FREQÜENCIA DE ENRAIZAMENTO "IN VITRO"}

O comportamento dos 3 clones (GO 250; GO 669 e GO 682), quanto ao en raizamento "in vitro", pode ser analisado através da Figura 11. O meio de cultura empregado foi o de GONÇALVES (1980), suplementado com os diferentes tratamentos descritos no item 3.5.

Nesta fase, os 3 clones apresentaram sintomas de clorose foliar e alguns pontos necróticos. Os clones GO 250 e GO 682 permaneceram com "calos", aglomerados de células não diferenciadas, na base das folhas. A oxidação afetou somente o clone GO 669, embora continuasse com o maior vigor de en raizamento, seguido do GO 682 e GO 250, concordando com os resultados das fases anteriores. 


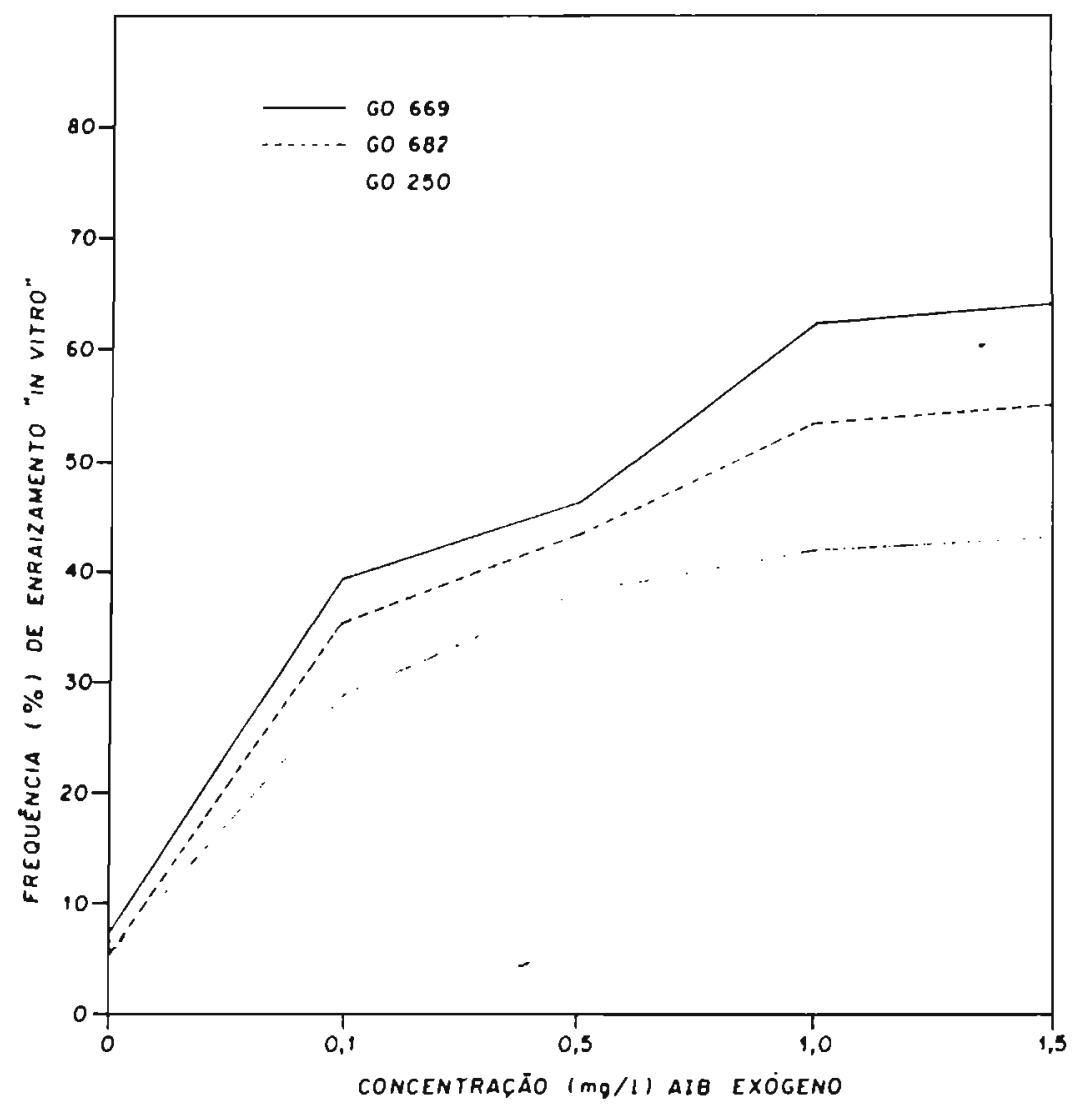

Figura 11. Freqüencia de culturas dos clones GO 250; GO 669 e GO 682 que desenvolveram raiz, em meio de cultura básico de GONÇALVES (1980), suplementado com 0,$0 ; 0,1 ; 0,5 ; 1,0$ e $1,5 \mathrm{mg} / \mathrm{l}$ de $A / B$ 
As Figuras 12,13 e 14 apresentam en raizamento das plântulas dos clones GO 682; GO 669 e GO 250, cultivados em meio de cultura indutor de en raizamento, segundo GONÇALVES (1980), e suplementado com 1,0 mg/l de AlB (T4).

Os resultados deste ensaio são indicativos de que os 3 clones testados apresentam potencial rizogênico, embora diferenciados quanto a freqüência do enraizamento. $O$ meio de cultura suplementado com taxas crescentes de $A / B \quad(0,0 ; 0,1$; $0,5 ; 1,0 ; 1,5 \mathrm{mg} / \mathrm{l})$ apresentou efeitos crescentes proporcionais no enraizamento, sen do que em concentrações superiores a 1,0 mg/l a resposta não foi exp ressiva, indican do a con centração ótima de suprimento de auxina exógena.

As freqüências de en raizamento (40-70\%) foram superiores às encontradas por outros autores (GONÇALVES, 1982; BAJAJ, 1986; MCСOMB \& BENNETT, 1986; KLEE \& ESTELLE, 1991; SILVA, 1992). Acredita-se que o en raizamento direto "in vitro" possa ser efetivamente melhorado com a composição de meio empregada nesta trabalho. BARBOSA (1992) sugere, ainda a associação do AlB com ácido naftalenoacético (ANA) e/ou floroglucinol, investigações ainda necessárias na otimização do processo. 


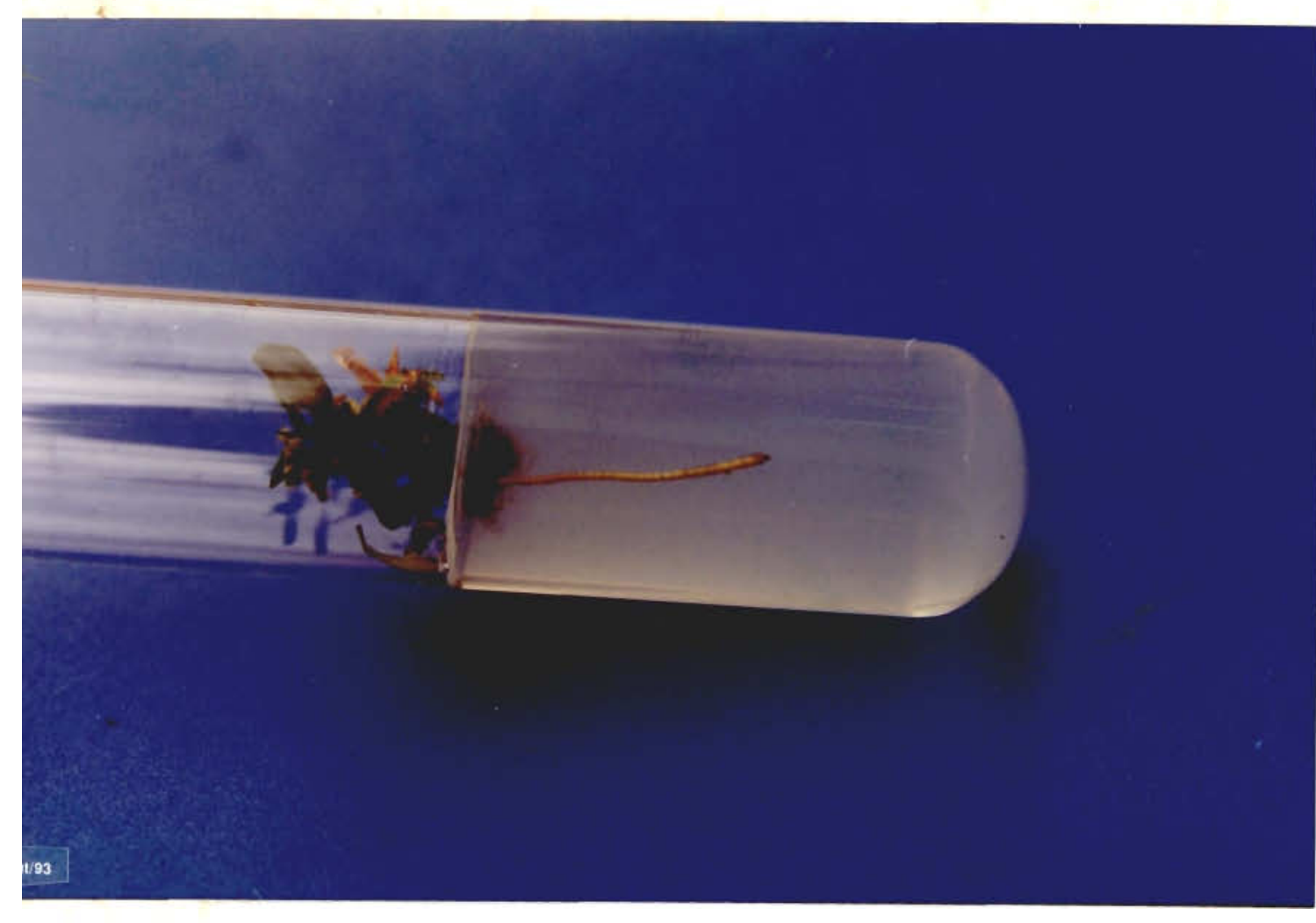

$\frac{1}{0}$

㐫

$\infty$

$\infty$

0

(1)

สิ

닌

$\frac{2}{0}$

U

$N$

$\infty$

0 은

$\stackrel{0}{\stackrel{4}{c}: ㄷ ㅡ . ~}$

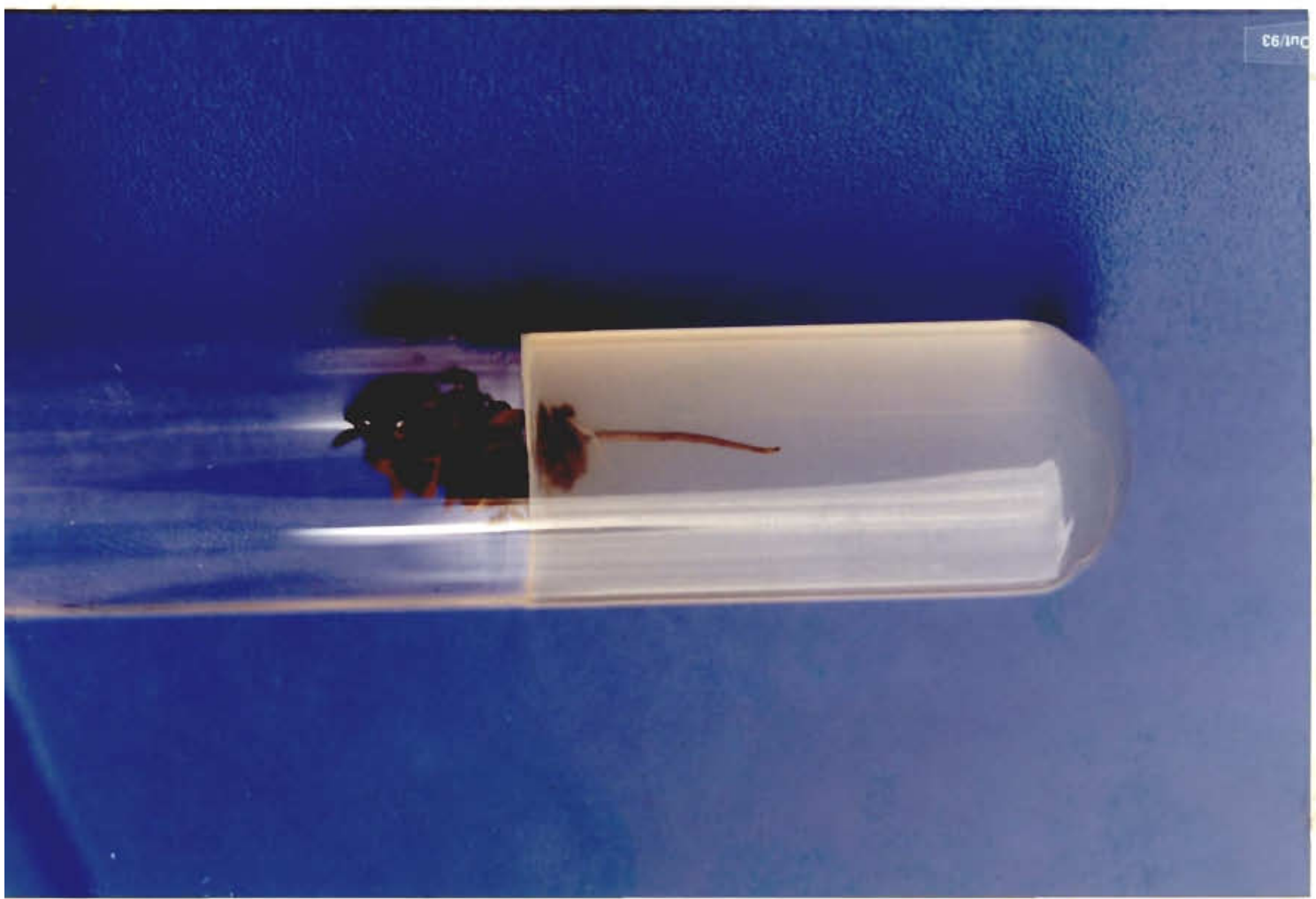

응 둔

o $\frac{0}{0}$

ㄴ

i $x$

甚

() $n$

d $\frac{2}{0}$

- $\frac{10}{6}$

$+=$

E

N $\geq$

药 约

$m$

(1)

N

(n)

ㄴํㄴ

는 


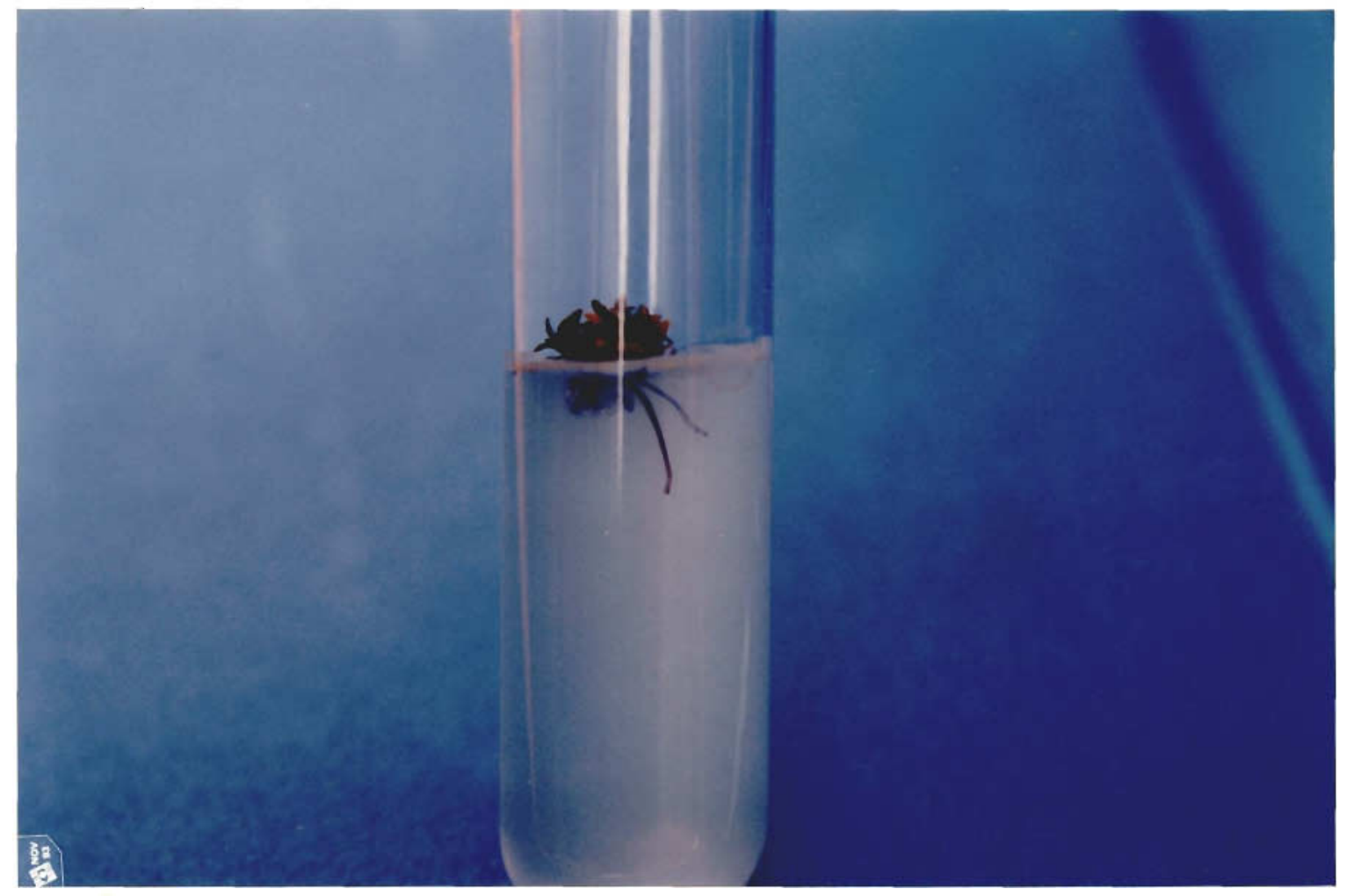

Figura 14. Enraizamento de gemas, do clone GO 250 , de Eucalyptus grandis Hill ex Maiden "in vitro" 
4.4 COMPORTAMENTO DOS CLONES EM PRODUÇĀO DE MASSAS DE MATÉRIAS FRESCA E SECA, "IN VITRO-

O comportamento dos clones (GO 250; GO 669 e GO 682), em relação à produção de massas de matérias fresca e seca, das plântulas que apresentaram ou não raiz, pode ser comparado através dos histogramas das Figuras 15 e 16.

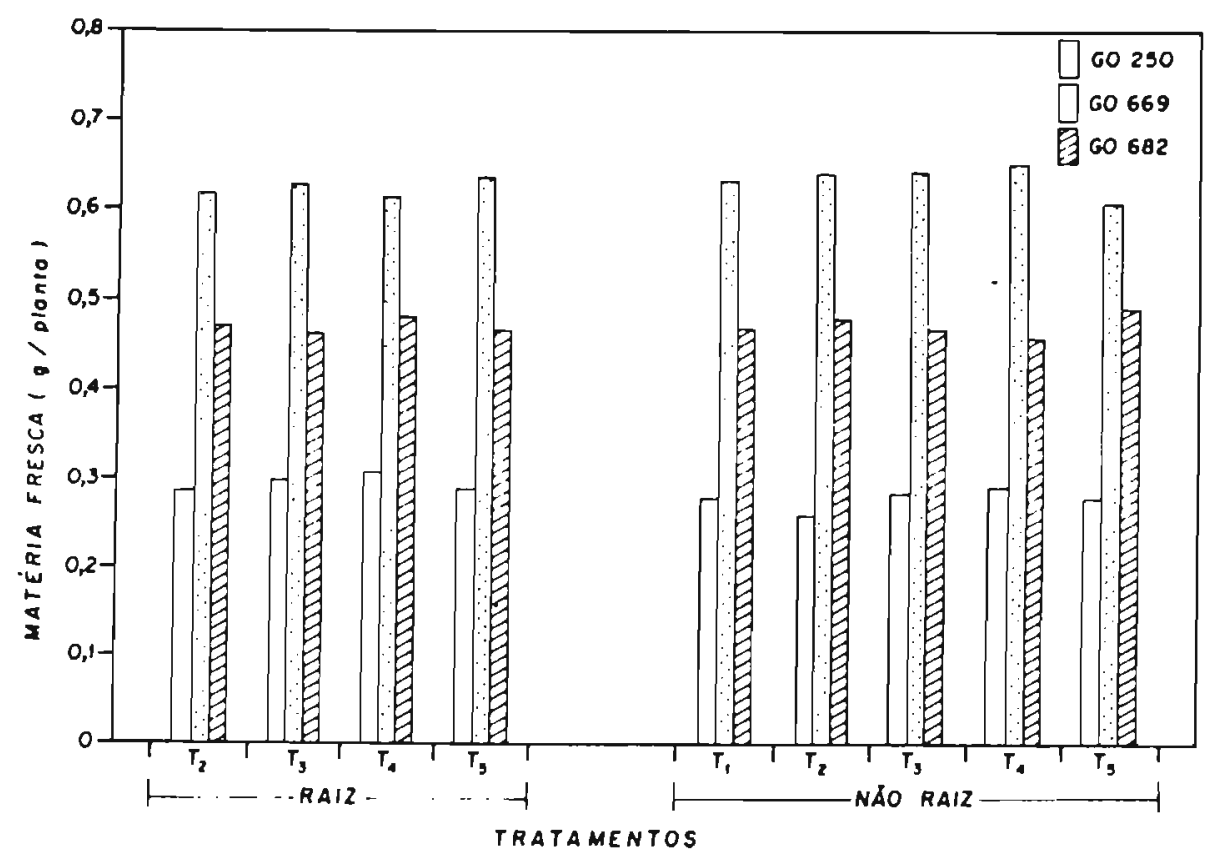

Figura 15. Comportamento dos clones GO 250; GO 669 e GO 682, em relação à produção de massa de matéria fresca (g/planta) das brotações que enraizaram, ou não. Os números representam valores médios de 15 repetições. O T1-grupo com raiz, não apresentou material suficiente para a determinação. 


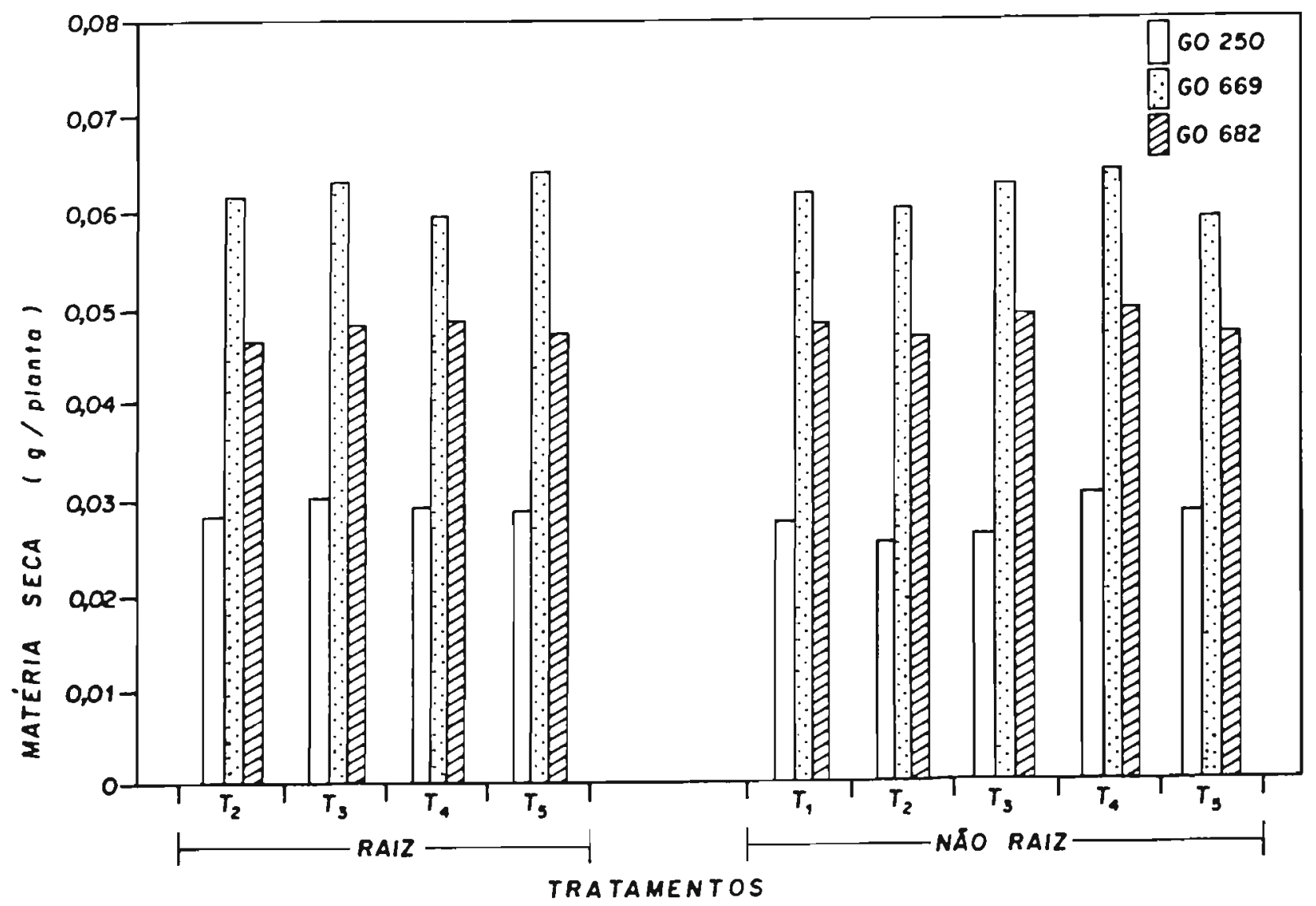

Figura 16. Comportamento dos clones GO 250; GO 669 e GO 682 , em relação à produção de massa de matéria seca (g/planta) das brotações que en raizaram, ou não. Os números representam valores médios de 15 repetições. O T1-grupo com raiz, não apresentou material suficiente para a determinação. 
Não houve diferença significativa, ao nivel de $5 \%$ de probabilidade (Tabelas 1 e 2 - Apêndice) entre os tratamento para a produção da MF e MS. De uma maneira geral a MS acompan hou a MF. Os resultados indicam que a suplementação com auxina não inibiu ou estimulou o desenvolvimento da parte aérea das plantas, uma vez que as amostras para estas análises consistiam basicamente da parte aérea e um primórdio do sistema radicular, de massa insignificante em relação à planta inteira.

A auxina parece ter influenciado tão somente a freqüência de iniciação e o geotropismo do processo de en raizamento da planta. Embora seja estabelecido que a substância desempen ha importante papel na elongação celular em segmentos cortados de plantas (JACOBS \& RAY, 1976; KLEE \& ESTELLE, 1991), permanece difícil a demonstração de sua ação na elon gação de partes aéreas de plantas intactas (HALL et alii, 1985). Alguns autores descrevem, ainda, redução nos internódios de plantas submetidas à ação de auxinas, e acreditam ser devido à redução do número de células por internódio (LINCOLN et alii, 1990; MIRZA \& MAHER, 1980; WIL SON et alii, 1990). 
4.5 COMPORT AMENTO DOS ClONES EM RELAÇÃo AO TEOR PROTÉICO

O comportamento dos clones (GO 250; GO 669 e GO 682), em relação ao teor protéico das plântulas que apresentaram ou não raiz, pode ser comparado através do histograma da figura 17.

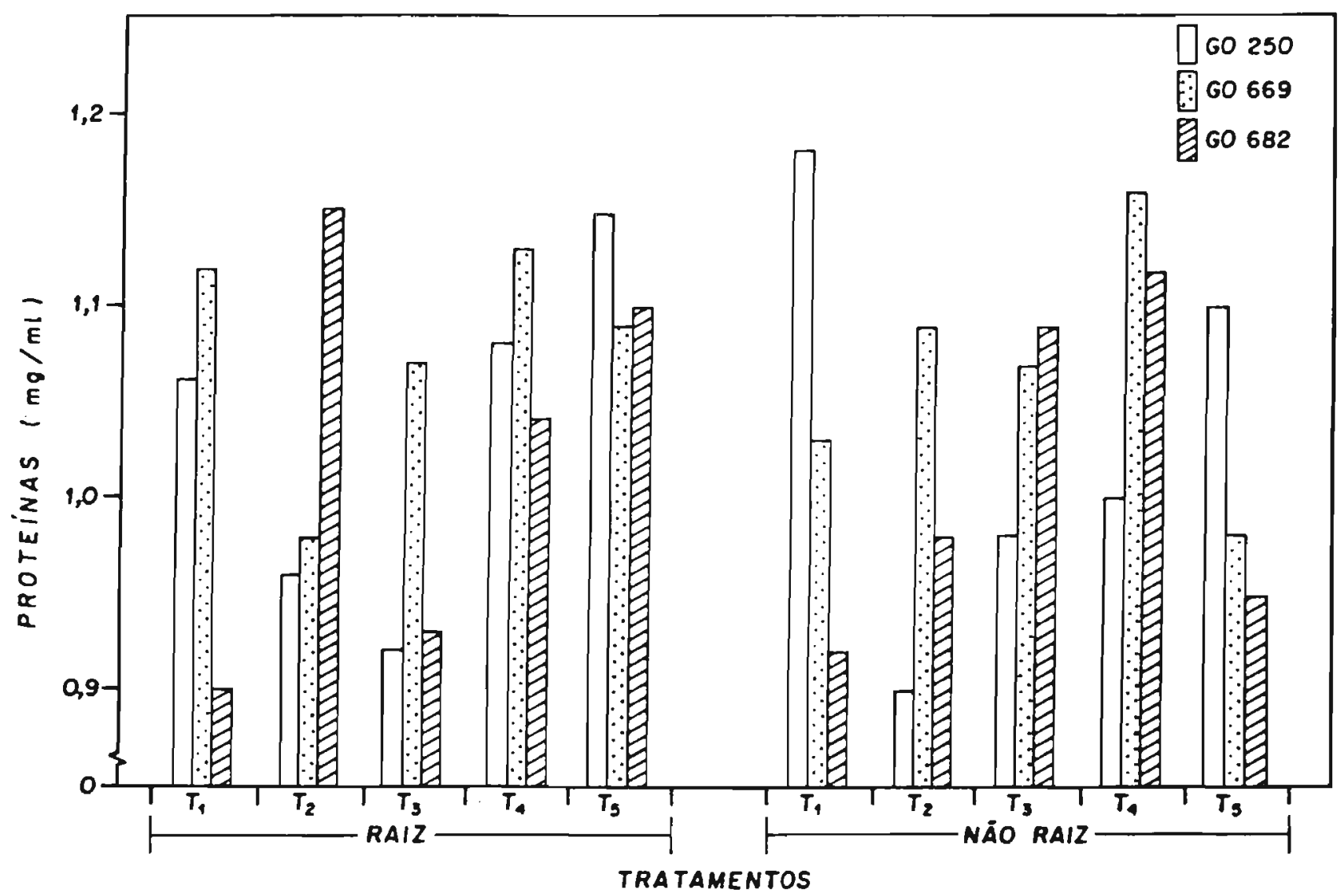

Figura 17. Comportamento dos clones GO 250; GO 669 e GO 682, em relação ao teor protéico $(\mathrm{mg} / \mathrm{ml})$ das brotações que enraizaram, ou não. Os números represen tam valores médios de 5 repetições, analisadas com 3 duplicat as cada. 
Os resultados não permitem uma avaliação mais precisa da influência da suplementação de auxina sobre o teor protéico das plantas estudadas. Os valores variaram aleatoriamente dentro dos tratamentos, e entre os clones (Tabela 3 Apêndice), e isto talvez seja devido à diferença de constituição das amostras analisadas, como presen ça ou não de calos, porções de tecidos necróticos e material fibroso e constituinte de caules e ramos.

Embora a dificuldade de uma avaliação precisa, os dados parecem indicar que não houve indução da produção de proteínas pela ação da auxina AlB. Isto pode ser devido ao pequeno tempo de observação das plantas no meio de cultura indutor do en raizamento. Nesta fase de iniciação da raiz, estudos fisiológicos e moleculares indicaram a hiperpolarização da membrana plasmática, e as mudanças nas estruturas da parede celular, como as primeiras respostas à auxina (JACOBS \& RAY, 1976; MCCLUBE \& GUILFOYLE, 1987; THEOLOGIS, 1986; HICKS et alii, 1989). Assim, acreditamos que um en foque mais interessante da ação da auxina sobre o metabolismo celular, talvez seja o acompanhamento da sintese de carboidratos, principalmente os polímeros constituintes da parede celular, como celulose, hemicelulose e pectina; e também a lignina, resultado do metabolismo do fenilpropano. 
KLEE et alii (1987); MEDFORD et alii (1989) e KLEE \& ESTELLE (1991) observaram, ainda, que o acréscimo de auxina estimula a indução da formação da raiz, inclusive as adventícias, mas não influenciam no crescimento (massa) da raiz. Isto pode indicar que as auxinas possuem especificidade de ação, e apenas na iniciação do processo, sem interferir em outras vias metabólicas.

\subsection{ATIVIDADE ENZIMÁTICA DE FENILALANINA AMÓNIA-LIASE}

A Figura 18 apresenta a atividade enzimática da fenilalanina amônia-liase (PAL), nas plântulas que apresentaram ou não raiz, quando submetidas a 5 diferentes concentrações de AlB exógeno, em meio de cultura indutor do en raizamen to "in vitro". Os valores da atividade em MKat.(Kg. Proteína) ${ }^{-1}$ foram calculados através de fórmula específica, descrita no item 3.5.4.

Analisando-se a Figura 18, observa-se que a enzima PAL não foi induzida pela ação do suprimento crescen te em auxina exógena (A|B), mas as plantas que enraizaram apresentaram maiores valores de atividade, isto em relação aquelas que não 
enraizaram. Por ser a enzima iniciadora do metabolismo do Fenilpropano, 0 resultado sugere maior fluxo e consequentemente incremento da produção de compostos flavonóides nas plantas em processo de enraizamento.

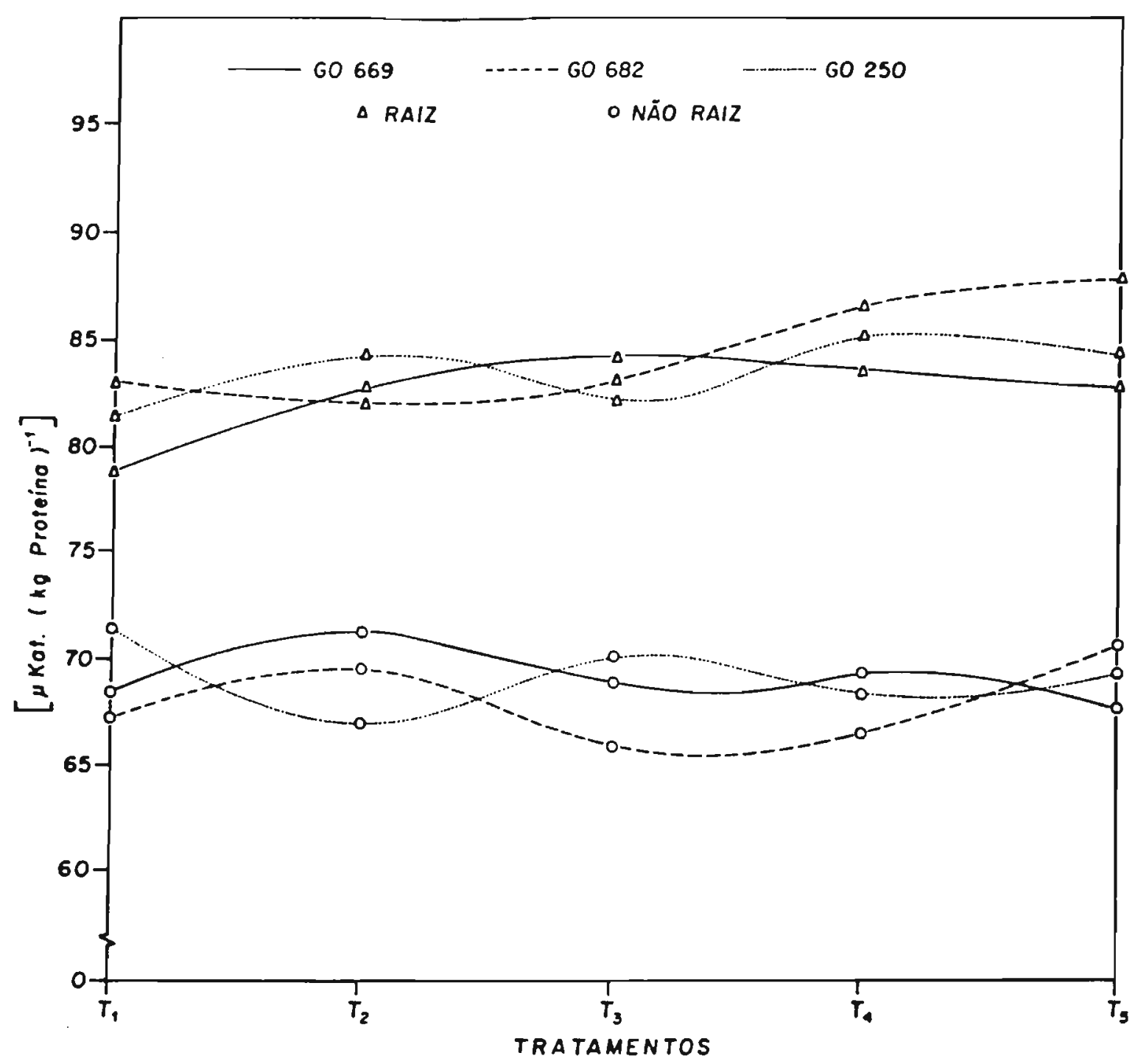

Figura 18. Efeito do suprimento de auxina (AlB) exógena sobre a atividade da enzima fenilalanina amónia-liase (PAL), no enraizamento direto de brotações de Eucalyptus grandis Hill ex Maiden (clones GO 250, GO 669 e GO 682), cultivadas "in vitro" 
Assim, observamos que embora o aumento de auxina exógena tenha promovido maior freqüencia de enraizamento, não estimulou contudo, a atividade da PAL. A resposta da enzima ao suprimento exógeno de auxina foi investigada por vários autores (JONES, 1984; FUNK \& BRODELIUS, 1990; OZEKI et alii, 1990), a maioria acredita que o decréscimo em auxina exógena, e o aumento em citocinina exógena, resultam em aumento da atividade da PAL em poucos dias.

Estudos moleculares mais esclarecedores vêm confirmando a indução da PAL, e consequentemente do metabolismo do Fenilpropano, pelos diversos estimulos estressantes, como radiação ultra-violeta, infecção por fitopatógenos, excisões, etc. (ORNDORFF et alii, 1988; OZEKI, 1990; YOSHIOKA, 1992; YAMADA, 1992). Não foi encontrado contudo, nenhum registro da ação direta e a nivel molecular, da auxina exógena na indução da enzima.

Pelo visto, parece que a indução do metabolismo do Fenilpropano deve acontecer mais pela ação da auxina endógena no momento do enraizamento, e que as mesmas seriam protegidas da oxidação pela ação de compostos flavonóides (dihidroflavonóides), resultado deste matabolismo. 


\subsection{ATIVIDADE ENZIMÁTICA DE GLUCOSE-6-FOSFATO-DESIDROGE-} NASE (G-6P-DH)

A Figura 19 apresenta a atividade enzimática da glucose-6fosfato-desidrogenase $\quad(G-6 P-D H), \quad$ nas plântulas que apresentaram ou não raiz, quando submetidas a 5 diferentes concentrações de AIB exógeno, em meio de cultura indutor do enraizamento "in vitro". Os valores da atividade em mKat (Kg. Proteina) ${ }^{-1}$ foram calculados através de fórmula específica, descrita no item 3.5.5.

A Figura 19 revela que a enzima glucose-6-fosfato desidrogenase, pertencente ao Metabolismo Primário, não apresentou mudanças significativas no seu padrão de indução, pelo suprimento crescente de AIB, mesmo nas concentrações mais elevadas.

Os resultados de atividade específica da G-6P-DH são concordantes com aqueles encontrados em produção de massa fresca e seca e o teor protéico, já descritos. Isto porque evidenciam nâo ter ocorrido variação significativamente mensurável dos metabolismo celular primário. Assim, tudo indica que a auxina AlB deva possuir ação específica na 
hiperpolarização da membrana, e desestruturação da parede celular, quando da iniciação do en raizamento (KLEE \& ESTELLE, 1991), e não exercendo influência no Metabolismo Primário das plantas.

A cinética e o modo de ação da enzima, permanecem pouco compreendidos a nível molecular em pilantas (BOGATEK et alii, 1989). Em células animais e de microorganismos, contudo, estudos moleculares mais recentes $v e m$ acrescen tando novas informações, demonstrando a sua importância no metabolismo celular primário (KURLANDSKY et alii, 1988; PARMJIJ et alii, 1987; HO et alii, 1988; BRIGHT et alii, 1993). 


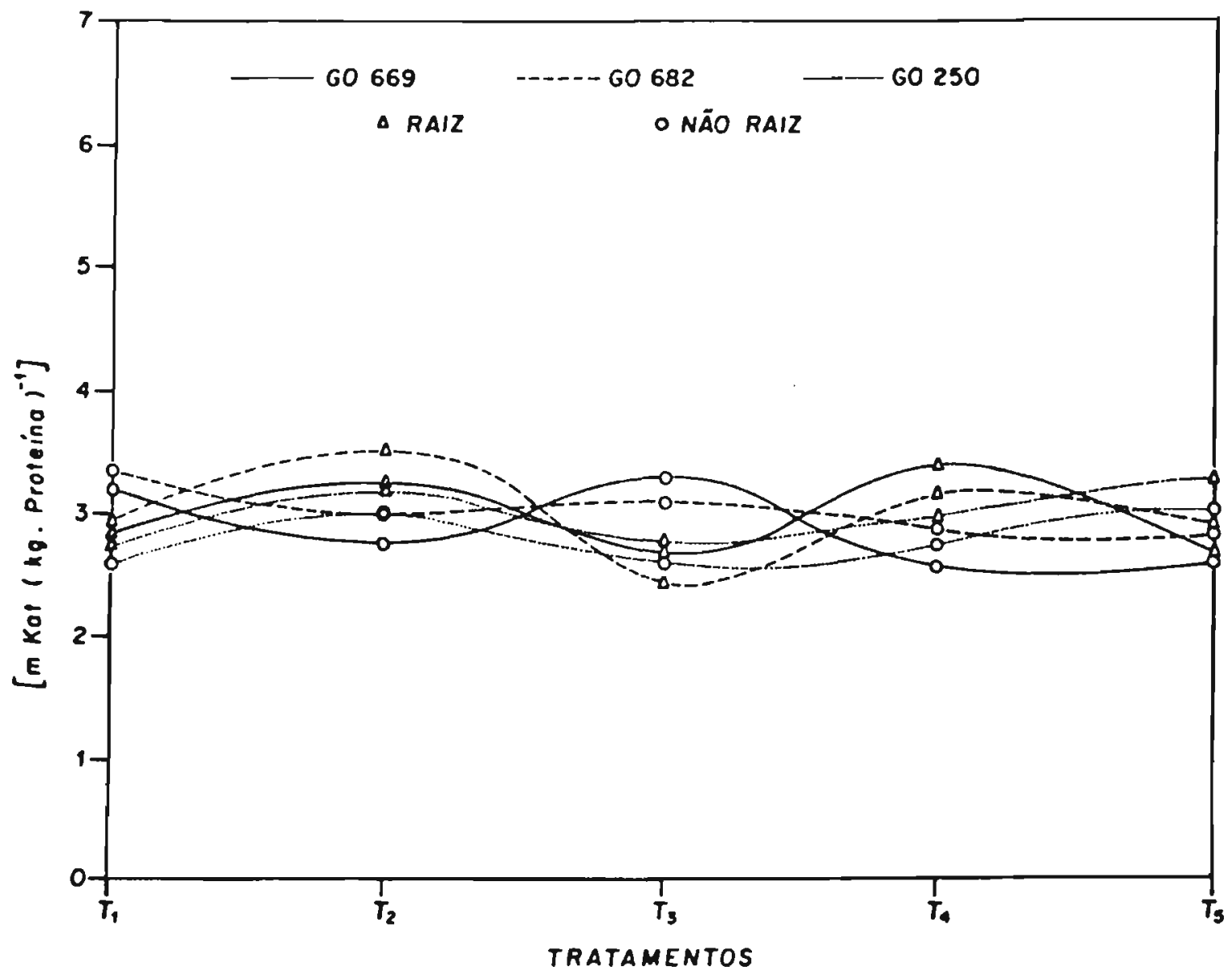

Figura 19. Efeito do suprimento crescente de auxina exógena (A|B) sobre a atividade da enzima glucose-6-f osfatodesidrogenase $(G-6 P-D H)$, no enraizamento direto de brotações de Eucalyptus grandis Hill ex Maiden (clones GO 250, GO 669 e GO 682), cultivadas "in vitro" 


\section{CONCLUSÕES}

Considerando as condições em que os experimentos foram conduzidos e os resultados obtidos, concluiu-se que:

- existem variações de comportamento dos clones (GO 250, GO 682 e GO 669) de E. grandis Hill ex Maiden, quanto ao estabelecimento, multiplicação, elongação e en raizamen to direto das gemas "in vitro";

- os meios de cultura indutor da elongação das gemas e en raizamento podem ser melhorados por modificaçōes no balanceamento entre auxina-ácido indolilbutírico (AIB) e 
cinetina-benzilaminopurina (BAP) exógenos. Suplementação, cinco vezes superior, de ambas as substâncias reguladoras $(0,1$ para $0,5 \mathrm{mg} / \mathrm{I})$ na elongação; e aplicação isolada de AlB, na concentração de $1 \mathrm{mg} / \mathrm{l}$, para a fase do en raizamento;

- o suprimento de auxina (AIB) exógena promoveu maior freqüência de en raizamento das plantas, mas não influenciou no crescimento da parte aérea e raiz; detectado pela produção de MF e MS, determinação do teor protéico e atividade da enzima G-6P-DH, rep resentante do metabolismo celular primário. A enzima PAL, iniciadora do Metabolismo do Fenilpropano, não foi igualmente estimulada pela auxina exógena;

- a enzima PAL teve a sua atividade significativamente aumentada durante o processo de en raizamento, o que sugere maior produção de compostos flavonóides (dihidroflavonóis) pelo Metabolismo do Fenilpropano. Estes compostos funcionariam como protetores das auxinas endógenas, por sua ação inibitória dos processos de oxidação, e manutenção do estado reduzido dos tecidos, condição associada com a reversão à juvenilidade.

- os resultados obtidos sugerem que o comportamento da enzima PAL, iniciadora do metabolismo dos flavonóides, pode ser adotado como um bom parâmetro para o estudo do complexo 
processo de en raizamento das plantas superiores "in vitro". A enzima G-6P-DH, contudo, por pertencer ao metabolismo celular primário ou intermediário, e por não ser a única via precursora de compostos aromáticos formados a partir da eritrose-4-fosfato, não constitui parâmetro tão adequado quanto a PAL. 


\section{REFERÊNCIAS BIBLIOGRÁFICAS}

ABDULLAH, A.A.; GRACE, J. \& YEOMAN, M.M. (1989) Rooting and establishment of Calabrian pine plantlets propagated in vitro: influence of growth substances, rooting medium and origin of explant. New Phytologist, 113(2):193-202.

ABSOLOM, D.R. (1986). Basic methods for the study of Phagocytosis. In: Methods in Enzymolozy, (New York:Academic Press), v.132, pp. 121, 161-162. 
ARJONA, C.; WELKERRING de TACCHINI, E. \& ROSELL, G.A. (1990). In vitro rooting of rootstook Colts. Turrialba, $40(1): 82-87$.

BAJAJ, Y.P.S. (1986) Biotechnology of tree improvement for rapid propagation and biomass energy production. In: Biotechnology in Agriculture and Forestry, Y.P.S. BAJAJ, ED. ( Berlin: Springer-Verlag), v.1, pp. 49-64.

BARBOSA, W.; CAMPO-DALL'ORTO, F.A.; OJIMA, M.; MARTINS, F.P.; BOVI, V. \& CASTRO, J.L. (1992). Produção de mu das de figueira "Roxo de valinhos" através da cultura "in vitro". O Agronómico, Campinas, $44(1,2,3): 6-10$.

BAULCOMBE, D.C.; KRONER, P.A. \& KEY, J.L. (1981). Auxin and gene regulation. In: Levels of Genetic Control in Development, S. SUBTELNY \& U.K. ABBOTT, eds. (New York: Alan R. Liss, Inc.), pp.83-97.

BEERHUES, L.; WIERMANN, R. \& ROBENEK, H. (1988) Chalcone synthase from spinach (spinacea oleracea) immunofluorescence and immunogold localization. Planta, Heidel berg. 173:544-53. 
BEERHUES, L.; FORKMANN, G.; SCHOPKER, H.; STOTZ, G. \& WIERMANN, R. (1989) Flavanone 3-hydroxylase and dihydroflavonol oxigenase activities in anthers of Tulipa. The significance of the tapetum fraction in flavonoid metabolism. Joural-of-Plant-Physiology. 133:743-746.

BERGMAYER, H.U. (1975). Methoden der Enzymatischen Analyse (Weinheim:Verlag Chemie), v.1.

BLOMSTEDT, C.; CAMERON, J.; WHITEMAN, P. \& CHANDLER, S.F. (1991). Micropropagation of junenile Eucalyptus regnans (mountain ash.). Australian Journal of Botany, 39(2):179-186.

BOGATEK, R.; ZARSKA-MACIEJEWSKA, B.; SINSKA, I. \& LEWAK, S. (1989). The embryonic axis controls lipid catabolism in cotyledons of apple seeds during germination. Physiologia Plantarum, 76:557-562.

BOLWELL, G.P.; ROBBINS, M.P. \& DIXON, R.A. (1985) Metabolic changes in elicitor-t reated bean cells: enzymatic responses associated with rapid changes in cell wall components. European Journal of Biochemistry, Berlin. 148:571-8. 
BRIGHT, J.R.; BYROM, D.; DANSON, M.J.; HOUGH, D.W. \& TOWNER, P. (1993). Cloning, sequencing and expression of the gene encoding glucose dehydrogenase from the thermophilic archaeon Thermoplasma acidophilum. Eur. J. Biochimistry, $211: 549-554$.

BRITCH, L.; HELLER, G. \& GRISEBACH, H. (1981) Conversion of flavanone to flavone, dihydroflavonal and flavonol with an enzyme system from cell culture of parsley. Zeitsch rift fuer Nat urforsch unz, Tuebingen. 36:742-50.

BROETTO, F. (1991). Efeito da radiação UV e do ácido giberélico em algumas enzimas do metabolismo de flavonóides em suspensão de células de cenoura (Daucus carota L. sp p. sativus). Dissertação de Mestrado. Escola superior de Agricultura "Luiz de Queiroz", Universidade de São Paulo. $109 p$.

CALIS, I.; HOSNY, M.; KHALIFA, T. \& RUEDI, P. (1992). Phenylpropanoid glycosides from Marrubium alysson. Phytochemistry. 31(10):3624-26.

CAMM, E. \& TOWERS, G.H.N. (1973). Phenylalanine ammonialyse. Phytochemistry. 12:961-73. 
DALKIN, K.; EDWARDS, R.; EDINGTON, B. \& DIXON, R.A. (1990). Stress responses in alfafa (Medicago sativa L.). I. Induction of phenylpropanoid biosynthesis and hydrolytic enzymes in elicitor treated cell suspension cultures. Plant Physiology, $92(2): 440-446$.

DIXON, R.A.; BLYDEN, E.R.; DRON, M.; HARRISON, M.J.; LAMB, C.J.; LAWTON, M.A. \& MAVANDAD, M. (1989). Regulation of gene expression in biological stressed bean cell cultures. In: Primary and Secondary Metabolism of Plant Cell Cultures, W.G.W. KURTZ, ed (Berlin: Springer Verlag), v.2, p p.266-273.

DOLCET-SANJUAN, R.; MOK, D.W.S. \& MOK, M.C. (1990). Micropropagation of Pyrus and Cydonia and their responses to Fe-limiting conditions. Plant Cell Tissue and Organ Culture, $21:(3): 191-199$.

DOUGLAS, C.J.; ELLARDI, M.; HAUFFE, K.D.; MOLITOR, E.; DESA, M.M.; REINOLD, S.; SUBRAMANIAM, R. \& WILLIAMS, F. (1992). General phenylpropanoid metabolism-regulation by environmental and developmental signal. Recent Advances in Phytochemistry, 26:63-89. 
EDWARDS, K.G. \& STOKER, J.R. (1967). Biosynthesis of coumarin: The isomerization stage. Phytochemistry, Oxford. $6: 655-661$.

EVANS, M.L. (1985). The action of auxin on plant cell elongation. CRC Critical Rewiews in Plant Science, 2:317365.

FRITSCH, H. \& GRISEBACH, H. (1975). Biosynthesis of cyanidin in cell cultures of Haplopappus gracilis. Phytochemistry, Oxford, 14:2447-52.

FUNK, C. \& BRODELIUS, P.E. (1990) Phenylpropanoid metabolism in suspension cultures of Vanilla planifolia Andr. 11. Effects of precursor feeding and metabolic inhibitors. Plant-Physiology. 94:95-101.

GLEITZ, J. \& SEITZ, H.U. (1989). UV-induction of chalcone synthase in cell suspension cultures of carrot (Daucus carota L. spp. sativus):Evidence for two different forms of chalcone synthase. Planta, Heidelberg. 179:323-30.

GLEITZ, J. (1989) Die regulation der lichtinduzierten anthocyansynthase in zellkulturen von Daucus carota L. Tuebingen, Lissertation - Universitat Tuebingen. 193p. 
GONÇALVES, A.N. (1982). Reversão à juvenilidade e clonagem de Eucalyptus urophyla, S.T. Blake "in vitro". Tese de Doutorado. Escola Superior de Agricultura "Luiz de Queiróz", Universidade de São Paulo. $97 p$.

GONÇALVES, A.N.; MACHADO, M.A.; CALDAS, L.S.; SHARP, W.R.; MELLO, H.D.A. (1980). Tissue culture of eucalyptus. In: Plant Cell and Tissue Culture, W.R. SHARP; P.O. LARSEN \& E.F. PADDOCK, eds. (Columbus: Ohio State Press), pp. 509526.

GORDON, W.R. \& KOUKKARI, W.L (1978). Circadian rhythmicity in the activities of phenylalanine ammonia-lyase from Lemna perpusilla and Spirodela polyrhiza Plant Physiol., 62:612615.

GRAHAM, T.L.; KIM, J.E. \& GRAHAM, M.Y. (1990) Role of constitutive isoflavone conjugates in the accumulation of glyceolin in soybean infected with Phytophthora megasperma. Molecular-Plant-Microbe-Interactions, 3(3):157166.

GRAYER, R.J. (1989) Flavonoids. In: Methods in Plant Biochemistry - Plant Phenolics, J.B. HARBORNE, ed. (San Diego: Academic Press), v.1, pp.283-323. 
GROTHGE, M.T. (1992). Efeito de várias fontes de nitrogênio na multiplicação de clones de Eucalyptus grandis Hill ex Maiden. Dissertação de Mestrado. Escola Superior de Agricultura "Luiz de Queiróz", Universidade de São Paulo. $86 p$.

GUPTA, S.C. \& CREASY, L.L. (1991). The effects of sunflower L-phenylalanine ammonia-lyase inactivating factor on Rhodotorula glutinis L-pheylalanine ammonia-lyase. Phytochemistry. 30(1):85-88.

HAGEN, G.; KLEINSCHMIDT, A. \& GUILFOYLE, T. (1984). Auxinregulated gene expression in intact soybean hypocotyl/ and excised hypocotyl/sections. Planta, 162:147-153.

HAGENDOORN, M.J.M; TRAAS, T.P.; BOON, J.J. VAN-DER-PLAS, L.H.W. (1990). Orthovanadate induced lignin production, in batch and continuous cultures of Petunia hybrida. Journalof-Plant-Physiology. 137:72-80.

HAHLBROCK, K. (1981). Flavonoids. In: The Biochemistry of Plants, E.E. CONN, ed. (New York: Academic Press), pp. 42556. 
HAHLBROCK, K. \& GRISEBACH, H. (1979). Enzymic controls in the biosynthesis of lignin and flavonoids. In: Secondary Plant Products, E.E. BELL \& B.V. CHARWOOD, eds. (Berlin: Springer-Verlag) p p. 105-30.

HAHLBROCK, K. (1976). Regulation of phenilalanine ammonialiase activity in cell suspension cultures of Petroselinium hortense. Europ. J. Biochem., Berlin. 63:137-45.

HAHLBROCK, K. \& SCHEEL, D. (1989) Physiology and molecular biology of phenylpropanoid metabolism. Ann. Rev. Plant Physiol. Plant Mol. Biol.. 40:347-69.

HALL, J.L, BRUMMELL, D.A. \& GILLESPIE, J. (1985). Does auxin stimulate the elongation of intact plant stems? New Phytol., $100: 341$

HANSON, K.R. \& HAVIR, E.A. (1981) Phenylalanine ammonialyase. In: The Biochemistry of Plants, T. SWAIN, ed (New York: Academic Press), v.7, pp. 577-625.

HARBORNE, J.B. (1980) Plant phenolics. In: Encyclopedia of Plant Physiology, E.A. BELL \& B.V. CHARWOOD, eds. (Berlin: Springer Verlag), p p. 329-402. 
HARBORNE, J.B. \& WILLIANS, C.A. (1972). Flavonoids patterns in the fruits of the umbelliferae. Phytochemistry, Oxford. $11: 1741-50$.

HEDIN, P.A. \& PHILLIPS, V.A. (1992). Electron impact mass spectral analysis of flavonoids. J. Agric. Food Chem.., 40:607-611.

HELLER, W. \& FORKMANN, G. (1988). Biosynthesis. In: The Flavonoids, J.B. HARBORNE, ed. (London: Chapman and Hall).

HENKEL-RIEGER, R. (1989) Die bedeutung der flavonoid-3hidroxilase bei der anthocyanbiosynthese in suspension skulturen von Daucus carota L. Tuebingen, DiplomarbeitUniversitat Tuebingen. $82 p$.

HICKS, G.R.; RAYLE, D.L. \& LOMAX, T.L. (1989) The diageotropica mutant of tomato lacks high specific activity auxin binding sites. Science, 245:52-54.

HINDERER, W. \& SEITZ, H.U. (1988). Flavonoids. In: Cell Culture and Somatic Cell - Genetic of Plants. (New York: Academic Press), v.5, pp.23-48. 
HO, Y.S.; HOWARD, A.J. \& CRAPO, J.D. (1988) Cloning and sequence of a cDNA encoding rat glucose-6-p hosphate dehydrogenase. Nucleic Acids Research, 16 (15):7746-7747.

HOAGLAND, R.E. (1990). Alternaria cassiae alters phenylpropanoid metabolism in sickelpod ( Cassia obtusifolia). Journal-of-Phytopathology, 130(3):177-187.

HOWARD, B. (1990). Rooting potencial in cutting. The Garden, n.1, pp.608-611.

HRAZDINA, G.; KREUZALER, F. HALBROCK, K. \& GRISEBACH, H. (1976). Substrate specifity of flavanone synthase from cell suspension cultures of Parsley spp and structure of release products "in vitro". Archives of Biochemistry and Bioph ysics, Duluth. 175:392-9.

HRAZDINA, G. (1982). Anthocyanins. In: Advances in Research, I.B. HARBORNE \& J. MABRY, eds. (London: Chapman and Hall), pp. 641-79.

HRAZDINA, G.; LIFSON, E. \& WEEDEN, F. (1986). Isolation and characterization of blackwheat (Fagopyrum esculentum M.) chalcone synthase and its polyclonal antibodies. Archives of Biochemistry and Biophysics, Duluth. 247:414-9. 
IKEMORI, Y.K. (1987). Epicormic shoots from the branches of Eucalyptus grandis as an explant source for "in vitro" culture. Common. For. Rev., 66(4):351-56.

JACOBS, M. \& RAY, P. (1976). Rapid auxin-induced decrease in free space $\mathrm{pH}$ and its relationship to auxin-induced growth in maize and pea. Plant Physiol., 58:203-9.

JIA, Z.J. \& LIU, Z.M. (1992). Phenylpropanoid and iridoid glycosides from Pedicularis longiflora. Phytochemistry. $31(9): 3125-27$.

JONES, D.H. (1984). Phenylalanine ammonia-liase: Regulation of its role in plant development. Phytochemistry, oxford. 23:1349-59.

KAKEGAWA, K.; HATTORI, E.; KOIKE, K. \& TAKEDA, K. (1991). Induction of anthocyanin synthesis and related enzyme activities in cell cultures of Centaurea cyanus by UV-light irradiation. Phytochemistry. 30(7):2271-73. 
KLEE, H.J.; HORSCH, R.B.; HINCHEE, M.A.; HEIN, M.B.; HOFFMANN, N.L. (1987). The effects of overproduction of two Agrobacterium tumefasciens T-DNA auxin biosynthetic gene products in transgenic petunia plants. Genes Dev., 1:86-96.

KLEE, H.J. \& ESTELLE, M. (1991). Molecular genetic approaches to plant hormone biology. Annu. Rev. Plant Physiol., 45:529-51.

KOUKOL, J. \& CONN, E.E. (1961). The metabolism of aromatic compounds in higher plants. Purification and properties of the phenylalanine deaminase of Hordeum vulgare. The Journal-of-Biological-Chemistry. USA. 236 (10):2692-8.

KOUL. S.K.; TANEJA, S.C.; MALHOTRA, S. \& DHAR, K.L. (1993). Phenylpropanoids and (-)-ledol from two Piper species. Phytochemistry. 32(2):478-80.

KRE UZA LER, F. \& HAHLBROCK, K. (1975). Enzymic synthesis of aromatic compounds in higher plants. Formation of bisnoryangen in(4-h yd roxi-6[ 4-hy droxy styryl]2-pyrone) from pcoumaroy I-COA and malonyl-COA. Archives Biochimestry and Biophysics, Duluth. 169:84-90. 
KRE UZA LER, F.; RAGG, H.; HELLER, W.; TESCH, R.; WITT, I; HAMMER, D. \& HAHLBROCK, K. (1979). Flavanone synthase from Petroselinium hortense: molecular weight, subunit composition, size of messenger RNA and absence of pantheteinyl residue. Europ. J. Biochem., Berlin. 99:89-96.

KRE UZALER, F.; LIGHT, R.J. \& HAHLBROCK, K. (1979). Flavanone synthase catalyses $\mathrm{CO} 2$ exchange and decarboxylation of malonyI-COA. FEBS Letters, Amsterdam. $94: 175-8$.

KRIEKEN, W.M.; BRETELER, H. \& VISSER, M.H.M. (1991). Indolebutyric acid-induced root formation in apple tissue culture. Design for an experimental system, auxin metabolism and isolation of CDNA clones related to root initiation. Acta Horticulturae, n.289, p p. 343-344.

KURLANDSKY, S.B., HILBURGER, A.C. \& RICHARD LEVY, H. (1988). Glucose-6-p hosphate dehydrogenase from Leuconostoc mesenteroides: Ligand-induced conformational changes. Archives of Biochemistry and Biophysics, 264(1):93-102.

LIMA, W.P. (1993). Plantações Florestais. In: Impacto Ambiental do Eucalipto, W.P. LIMA, ed. (São Paulo: Editora da Universidade de São Paulo), pp.33-50. 
LIMA, W.P.; ZAKIA, M.J.B.; LIBARDI, P.L. \& SOUZA FILHO, A.P. (1990). Comparative evapotranspiration of eucalyptus, pine and cerrado vegetation measured by the soil water balance method. IPEF International, Piracicaba, 1:5-11.

LINCOLN, C.; BRITTON, J.H.; ESTELLE, M. (1990). Growth and development of the axrl mutants of Arabidopsis. Plant Cell. 2:1071-80.

LOAKE, G.J.; CHOUDHARY, A.D.; HARRISON, M.J.; MAVANDAD, M.; LAMB, C.J. \& DIXON, R.A. (1991). Phenylpropanoid pathway intermediates regulate transient expression of a chalcone synthase gene promoter. The Plant Cell. 3:829-840.

LOWRY, O.H.; ROSEBROUGH, N.J; FAAR, A.L.; RANDALL, R.J. (1951). Protein measurement with the folin phenol reagent. Journal of Biological Chemistry, 193:65-75.

MABRY, T.J. \& MARKHAM, K.R. (1975). Mass spectrometry of flavonoids. In: The Flavonoids, J.B. HARBORNE, T.J. MABRY, H. MABRY, eds (New York: Academic Press), pp.78-126.

MABRY, T.J. \& ULUBELEN, A. (1980). In: Biochemical Applications of Mass spectrometry, G.R. WALKER, O. DERMER, eds (New York:Wiley), pp.1131-48. 
MARKHAM, K.R. (1988). In: The Flavonoids-Advances in Research, J.B. HARBORNE, ed. (London:Chapman and Hall), v.2, p p. $427-468$.

MCCLURE, B.A. \& GUILFOYLE, T. (1987). Characterization of a class of small auxin-inducible soybean polyadenylated RNAs. Plant Mol. Biol., 9:611-24.

McCOMB, J.A. \& BENNETT (1986). Eucalypts (Eucalyptus spp.) In: Biotechnology in Agriculture and Forestry, Y.P.S. BAJAJ, ED. ( Berlin: Springer-Verlag), v.1, pp. 340-362.

MEDFORD, J.I.; HORGAN, R.; EL-SAWI, Z \& KLEE, H.J. (1989). Alterations of endogenous cytokinins in transgenic plants using a chimeric isopentenyl transferase gene. Plant Cell 4:403-13.

MESSNER, B.; BOLL, M. \& BERNDT, J. (1991) L-phenylalanine ammonia-lyase in suspension culture of spruce (Picea abies)- Induction by UV-light and fungal elicitor. Plant Cell Tissue and Organ Culture. 27: 267-274.

MIZRA, J.L \& MAHER, E.P. (1980). More 2,4-D resistant mutants. Arabidopsis Inf. Serv. 17:103-7. 
MIZUKAMI, H.; TOMITA, K. \& OHASHI, H. (1989) Anthocyanin accumulation and changes in activities of phenylalanine ammonia-lyase and chalcone synthase in roselle (Hibiscus sabdariffa L.) callus culture. Plant-cell-Reports. Japan. 8:467-470.

MO, Y; NAGEL, C. \& TAYLOR, L.P. (1992). Biochemical complementation of chalcone synthase mutants defines a role for flavonols in functional pollen. Proc. Natl. Acad. Sci. USA. 89:7213-17.

NADASKA, V. \& ERDELSKY, K. (1991) PAL and SDH-especific activity in elicitor-treated callus culture of Papaver somniferum L. during a growth period. Biologia- Bratislava. Czechoslovakia. 46:577-582.

NANDWANI, D. \& RAMAWAT, K.G. (1991). Callus culture and plantlets formation from nodal explants of Prosop is juliflora (Swartz). Indian Journal of Experimental Biology, 29(5):523527.

ORNDORFF, S.A.; CONSTANTINO, N.; STEWART, D. \& DURHAM, D.R. (1988). Strain improvement of Rhodotorula graminis for production of a novel L-phenylalanine ammonia-lyase. Applied and Environmental Microbiology. 54(4):996-1002. 
OZEKI, Y.; KOMAMINE, A. \& TANAKA, Y. (1990) Induction and repression of phenylalanine ammonia-lyase and chalcone synthase enzyme proteins and mRNAs in carrot cell suspension cultures regulated by 2,4-D. Physiologia Plantarum. 78:400-408.

PARMJIT, S.S.; ROESLER, W.J.; KHANDELWAL, R.L. \& ANGEL, J.F. (1987). Hormonal regulation of malic enzyme and glucose-6-p hosp hate dehydrogenase in adult rat liver. 623rd IBBG MEETING, Canterbury. 16:33-34.

REDMOND, J.W.; BATLEY, M.; DJORDJEVIC, M.A.; INESS, R.W.; KUEMPEL, P.L. \& ROLFE, B.G. (1986) Flavones induce expression of nodulation genes Rhizobium Nature, London, $323: 632-4$.

ROY, A.T. \& DE, D.N. (1990). Tissue culture and plant regeneration from immature embryo explants of Calotropis gigantea L.. Plant Cell Tissue and Organ Culture, 20 (3) 229-233.

RUSSEL, D.W. \& GALSTON, A.W. (1967). Flavonoid complexes in Pisum sativum. IV. The effect of red light on synthesis of kaempferol complexes and on growth in sub-apical internode tissues. Phytoch emistry. 6:791-7. 
SAPKO, O.A.; MUKHAMEDZHANOV, B.G. \& KUNAEVA, R.M. (1992). Formation of phenolic compounds in camel thorn tissue culture. Soviet-Plant-Physiology. 39(2):684-88.

SARAVITZ, C.H.; BLAZICH, F.A. \& AMERSON, H.V. (1991). in vitro propagation of Virginia pine from cotyledons. Journal of the American Society for Horticultural Science, $116(2): 362-365$.

SCHUTTE, H.R. (1985) Secondary Plant Substances: Special topics of the flavonoid matabolism. In: Progress in Botany. (Berlin: Springer Verlag), v.17, pp.i-f.

SERRES, R.; READ, P. HACKETT, W. \& NISSEN, P. (1990). Rooting of American chestnut microcuttings. Journal of Environmental Horticulturae. 8:(2):86-88.

SEYFERT, W. (1982) Beitrage zur genetik und enzymologie der flavonoide. Biologisches Zen tralblatt, Leipzig. 101:465-83.

SILVA, L.L. (1990). Propagação "in vitro" de Eucalyptus grandis Hill ex Maiden, a partir de gemas epicórmicas. Tese de Doutorado. Universidade Federal de Viçosa, Minas Gerais. $60 p$. 
STICH, K. EIDENBERGER, T.; WURST, F. \& FORKMANN, G. (1992). Enzymatic conversion of dihydroflavonols to flavan3,4-diols using flower extracts of Dianthus caryophyllus L. (carnation). Planta. 187:103-108.

TANAKA, T.; IINUMA, M.; YUKI, K. FUJII, Y. \& MIZUNO, M. (1992). Flavonoids in root bark of Pongamia pinnata. Phytochemistry, 31(3):993-8.

THEOLOGIS, A. (1986). Rapid gene regulation by auxin. Annu. Rev. Plant Physiol., 37:407-38.

VIEITEZ, A.M.; SANCHEZ, C. \& SAN-JOSE, C. (1989) Prevention of shoot-tip necrosis in shoot cultures of chestnut and oak. Scientia-Horticulturae. 41:1-2, 151-159.

WALKER, J.C.; LEGOCKA, J.; EDELMAN, L. \& KEY, J.L. (1985). An analysis of growth regulator interactions and gene expression during auxin-induced cell elongation using cloned complementary DNAS to auxin-responsive messenger RNAs. Plant Physiology, 69:332-337.

WEISS, D. \& HALEVY, A.H. (1991) The role of light reaction in the regulation of anthocyanin synthesis in Petunia carolla. Physiologia-Plantarum, 81(1):127-133. 
WILSON, A.K.; PICKETT, F.B.; TURNER, J.C. \& ESTELLE, $M$. (1990). A dominant mutation in Arabidopsis confers resistance to auxin, ethylene and abcisic acid. Mol. Gen. Genet., 222:377-83.

WONG, P.P.; ZUCKER, M. \& CREASY, L.L. (1974) Induction of phenylalanine ammonia-lyase in strawberry leaf disks-Action spectra and effects of wounding, sucrose and light. Plant Physiology, 54:659-665.

YAMADA, T.; TANAKA, Y.; SRIPRASERTSAK, P.; KATO, H.; HASHIMOTO, T.; KAWAMATA, S.; ICHINOSE, Y.; KATO, H.; SHIRAISHI, T. \& OKU, H. (1992). Phenylalanine ammonia-lyase genes from Pisum sativum: structure, organ-specific expression and regulation by fungal elicitor and suppressor. Plant Cell Physiol. 33(6):715-25.

YOSHIOKA, H.; SHIRAISHI, T.; KAWAMATA, S.; NASU, K.; YAMADA, T.; ICHINOSE, Y. \& OKU, H. (1992). Orthovanadate supresses accumulation of phenylalanine ammonia-lyase mRNA in pea epicotyls induced by elicitor from Mycosphaerella pinodes. Plant Cell Physiol. 33(2):201-204. 
ZIMMERMAN, R.H. \& MILLER, S.S. (1991). Orchard growth an fruiting of microp ropagated apple trees. Journal of the American Society for the Horticultural Science, New York, $116(5): 780-85$. 


\section{APÊNDICE}


Tabela 1 Produção de matéria fresca (grama/planta) dos clones GO 250; GO 682 e GO 669,-que enraizaram, e os que não apresentaram diferenciação em raiz, nos 5 tratamentos testados. Valores médios de 15 repetições/grupo.

\section{DIFERENCIACÃO}

\begin{tabular}{|c|c|c|c|c|c|c|}
\hline & \multicolumn{3}{|c|}{ RAIZ (C.V. $x=30,49$ ) } & \multicolumn{3}{|c|}{ NÃO RAIZ (C.V. $\quad x=32,65$ ) } \\
\hline & GO 250 & GO 682 & GO 669 & GO 250 & GO 682 & GO 669 \\
\hline T1 & - & - & - & $0,2821^{c}$ & $0,4720^{a b}$ & $0,6283^{a}$ \\
\hline $\mathrm{T} 2$ & $0,2854 \mathrm{C}$ & $0,4715^{a b}$ & $0,6235 a$ & 0,2619 & $0,4807^{a b}$ & 0,63899 \\
\hline T3 & 0,2973 & $0,4689 a b$ & $0,6276^{a}$ & $0,2835^{C}$ & $0,4710^{a b}$ & $0,6438^{a}$ \\
\hline T4 & $0,3040^{\circ}$ & $0,4824^{a b}$ & $0,6158^{a}$ & $0,2907 \mathrm{c}$ & $0,4615^{a b}$ & $0,6570^{a}$ \\
\hline T5 & $0,2892^{c}$ & $0,4729 a b$ & $0,6342^{a}$ & $0,2796^{\circ}$ & $0,4869^{a b}$ & $0,6120^{a}$ \\
\hline
\end{tabular}

Os contrastes entre as médias foram comparadas pelo teste de Tukey.

Médias seguidas de letras iguais não diferem, estatisticamente, ao nivel de $5 \%$ de probabilidade. O T1-grupo com raiz, não apresentou material suficiente para a determinação 
Tabela 2 Produção de matéria seca (grama/planta) dos clones GO 250; GO 682 e GO 669, que enraizaram, e os que não apresentaram diferenciação em raiz, nos 5 tratamentos testados. Valores médios de 15 repetições/grupo.

\section{DIFERENCIACĀO}

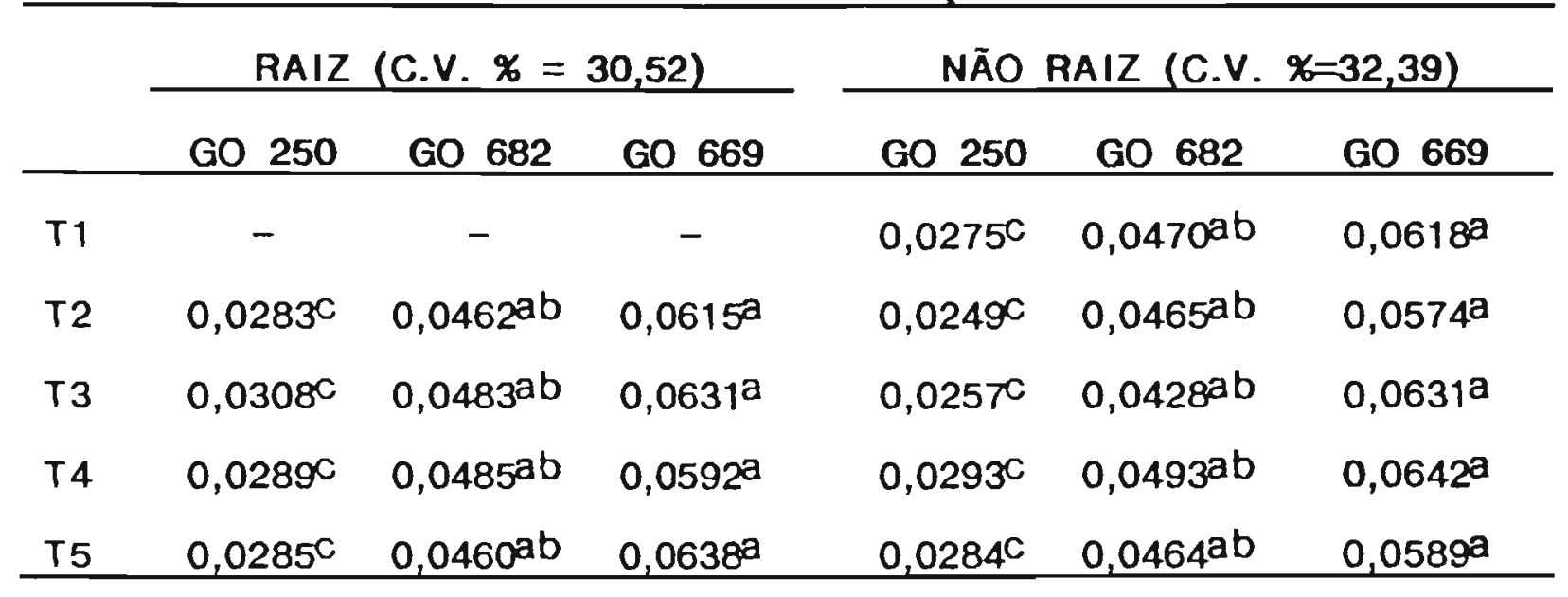

Os contrastes entre as médias foram comparadas pelo teste de Tukey.

Médias seguidas de letras iguais não diferem, estatisticamente, ao nível de $5 \%$ de probabilidade. O T1-grupo com raiz, não apresentou material suficiente para a determinação 
Tabela 3 Teor protéico (mg prot./ml) dos clones GO 250; GO 682 e GO 669, que enraizaram, e os que não apresentaram diferenciação em raiz, nos 5 tratamentos testados. Valores médios de 15 repetições/grupo, com 3 duplicata cada

\begin{tabular}{|c|c|c|c|c|c|c|}
\hline & \multicolumn{6}{|c|}{ DIFERENCIAÇĀO } \\
\hline & \multicolumn{3}{|c|}{ RAIZ (C.V. $x=8,22$ ) } & \multicolumn{3}{|c|}{ NÃO RAIZ (C.V. $\quad x=8,33$ ) } \\
\hline & GO 250 & GO 682 & GO 669 & GO 250 & GO 682 & GO 669 \\
\hline T1 & $1,06^{a}$ & $0,90^{a}$ & $1,12^{a}$ & $1,18^{\mathrm{a}}$ & $0,92^{\mathrm{a}}$ & $1,03^{\mathrm{a}}$ \\
\hline $\mathrm{T} 2$ & $0,96^{a}$ & $1,15^{\mathrm{a}}$ & $0,98^{a}$ & $0,90^{a}$ & $0,98^{a}$ & $1,09 \mathrm{a}$ \\
\hline T3 & $0,92^{\mathrm{a}}$ & $0,93^{a}$ & $1,07^{a}$ & $0,98^{a}$ & $1,09^{a}$ & $1,07^{a}$ \\
\hline $\mathrm{T} 4$ & $1,08^{a}$ & $1,04^{\mathrm{a}}$ & $1,13^{\mathrm{a}}$ & $1,00^{a}$ & $1,12^{\mathrm{a}}$ & $1,16^{\mathrm{a}}$ \\
\hline T5 & $1,15^{\mathrm{a}}$ & $1,10^{\mathrm{a}}$ & $1,09 \mathrm{a}$ & $1,10^{a}$ & $0,95^{a}$ & $0,98^{a}$ \\
\hline
\end{tabular}

